\title{
Thinking about Feathers: Adaptations of Golden Eagle Rectrices
}

Author(s): David H. Ellis and James W. Lish

Source: Journal of Raptor Research, 40(1):1-28. 2006.

Published By: The Raptor Research Foundation

DOI: http://dx.doi.org/10.3356/0892-1016(2006)40[1:TAFAOG]2.0.CO;2

URL: http://www.bioone.org/doi/

full/10.3356/0892-1016\%282006\%2940\%5B1\%3ATAFAOG\%5D2.0.CO\%3B2

BioOne (www.bioone.org) is a nonprofit, online aggregation of core research in the biological, ecological, and environmental sciences. BioOne provides a sustainable online platform for over 170 journals and books published by nonprofit societies, associations, museums, institutions, and presses.

Your use of this PDF, the BioOne Web site, and all posted and associated content indicates your acceptance of BioOne's Terms of Use, available at www.bioone.org/page/terms_of_use.

Usage of BioOne content is strictly limited to personal, educational, and non-commercial use.

Commercial inquiries or rights and permissions requests should be directed to the individual publisher as copyright holder. 


\title{
THE JOURNAL OF RAPTOR RESEARCH
}

\section{A QUARTERLY PUBLICATION OF THE RAPTOR RESEARCH FOUNDATION, INC.}

VOL. 40

MARCH 2006

No. 1

J. Raptor Res. 40(1):1-28

(c) 2006 The Raptor Research Foundation, Inc.

\section{THINKING ABOUT FEATHERS: ADAPTATIONS OF GOLDEN EAGLE RECTRICES}

\author{
DAVID H. Ellis ${ }^{1}$ \\ USGS Southwest Biological Science Center, Sonoran Desert Field Station, HC 1 Box 4420, \\ Oracle, AZ 85623 U.S.A.
}

Illustrations by JAMES W. LisH

Department of Physiological Sciences, Center for Veterinary Sciences, Oklahoma State University, Stillwater, OK 74079 U.S.A.

\author{
"Happy is the man whose lot it is to know \\ The secrets of the earth." \\ Euripides
}

\begin{abstract}
AвSTRACT- - The striking black and white plumage of the juvenile Golden Eagle (Aquila chrysaetos) provides an excellent opportunity to examine the possible selective forces influencing the strategic placement of dark pigment in birds. The conflict between opposing selective pressures (first, toward large white patches, which may allay aggression in adults, and second, toward dark plumage to promote camouflage and limit solar and abrasive wear) provides the stage whereon are revealed a score of pigmentation traits of potential adaptive value.

The general pigmentation trend is for zones that are more exposed to the sun to be darker than elsewhere. More specifically: (1) for rectrices and remiges, outer webs are darker than inner; (2) for those few feathers (e.g., central rectrices, some scapulars, and some tertials), where both inner and outer webs are heavily and nearly equally solar exposed, pigmentation is supplied similarly on both webs; (3) outermost primaries and rectrices are darkest of all and are structurally similar; (4) for central rectrices, subject to high levels of abrasion with substrate, the tip is paler (resultant flexibility may limit breakage); and (5) pigment is heavier along or on the rachis than on the webs.

Many of the traits listed above for the Golden Eagle are also found in other families of birds. Traits of the tail common to many species were a terminal pale tip, a subterminal dark band, rachis darker than vane, and outer webs darker than inner for both remiges and rectrices. The most widespread traits likely have adaptive value.
\end{abstract}

KeY Words: Golden Eagle; Aquila chrysaetos; adaptation; feather; molt; morphology; pigment.

PENSAMIENTOS ACERCA DEL PLUMAJE: ADAPTACIONES DE LAS RECTRICES DE AQUILA CHRYSAETOS

RESUMEN.-El llamativo plumaje blanco y negro de los individuos juveniles de Aquila chrysaetos provee de una oportunidad excelente para estudiar las posibles fuerzas selectivas que influyen sobre el posicionamiento estratégico del pigmento oscuro en las plumas de las aves. El conflicto entre presiones

1 Present address: Institute for Raptor Studies, HC 1 Box 4420, Oracle, AZ 85623 U.S.A.; email address: dcellis@theriver.com 
selectivas opuestas (primero, hacia parches blancos de gran tamaño que pueden apaciguar la agresividad en adultos y segundo, hacia un plumaje oscuro para promover el camuflaje y limitar el desgaste solar y abrasivo) provee de un escenario sobre el cual se muestra un gradiente de caracteres de valor adaptativo potencial.

El patrón general de pigmentación es que zonas que están más expuestas al sol son más oscuras que otras partes. De manera más específica: (1) para las rectrices y rémiges las partes externas de la red que conforma la pluma son más oscuras que las internas; (2) para aquellas pocas plumas (ej. rectrices centrales, algunas escapulares y algunas terciarias)en que tanto la parte interna como externa están expuestas al sol, la pigmentación está distribuida de forma similar en ambos lados; (3) las primarias y rectrices más externas son las más oscuras y son estructuralmente similares; (4) para las rectrices centrales, que se encuentran sujetas a altos niveles de abrasión con el sustrato, la punta es más pálida (la flexibilidad resultante puede prevenir su ruptura) y (5) el pigmento se encuentra más concentrado a lo largo o en el raquis que en la parte de la red de la pluma.

Muchos de los caracteres mencionados arriba para A. chrysaetos también son observados en otras familias de aves. Otros caracteres de la cola que también son comunes en muchas otras especies son puntas terminales pálidas, banda subterminal oscura, raquis más oscuro que las barbas y red externa que conforma la pluma más oscura tanto para las rémiges como para las rectrices. Los caracteres más comunes probablemente tienen algún valor adaptativo.

[Traducción del equipo editorial]

For this paper, I describe traits in the pigmentation and structure of the plumage of juvenile Golden Eagles (Aquila chrysaetos; see frontispiece) and compare these traits with those of older Golden Eagles and a variety of other raptors. For traits common to many species, I suggest likely functions, encouraging others to look more closely and thereby uncovering a wider variety of adaptive functions of feather peculiarities across the avian world. As stated by Tinbergen (1963:530), " . . . critical, precise, and systematic observation is a valuable and indispensable scientific procedure. ..."

The time-tested practice of ascribing adaptive significance to physical and behavioral traits of animals was somewhat discouraged with acceptance of the handicap principle (Zahavi and Zahavi 1997). The fundamental idea is that "waste can make sense" in social signaling (e.g., the peacock's [Pavo sp.] tail). But, as the Zahavis themselves allow (Zahavi and Zahavi 1997:230), traits fall into two classes: those with value as social signals (the handicap principle applies here) and those that are "of a bodily structure that makes its owner more efficient."

Of course, many traits have multiple functions, some with survival value, others with social significance. In the plumage of the juvenile Golden Eagle, there are broad white zones of presumed social significance and subtle pigmentation features that protect these zones from bleaching and erosion. This conflict between opposing selective pressures reveals adaptive pigmentation traits that may otherwise have been masked.
Most traits that are variably expressed, but common to all individuals of a species and are found in related species, have adaptive value (either socially or otherwise). One of the most fundamental ways to study natural selection and understand how it works to shape a species is to start "from an observable property of an animal of which the function is unknown, and [examine] in what respect it [i.e., the trait] contributes to survival . . .", (Tinbergen 1963:526). A second way is to compare the expression of a trait between related taxa (Hailman 1976). While it is desirable to thereafter test the value of a trait by careful experimentation, it should also be recognized that for some hypotheses a major "reason for not proceeding to experiment is the fact that it may be difficult or almost impossible in practice [to do so]" (Tinbergen 1963:530). Untested hypotheses, of course, remain conjectural.

From 50 years of naturalistic observation of the plumage of birds from around the world, I here present hypothesized functions for about 20 traits. Many of these can be, and I hope will be, tested. All will hopefully stimulate thought.

The Complexities of Eagle Plumage. The striking black and white plumage of the juvenile Golden Eagle (frontispiece) presents what appear to be important social signals. First, the white zones most likely allay parental aggression during the late nestling and pre-dispersal periods. Although the critical experiment has not been attempted, it is almost certain that a fledgling, if dyed to approximate adult color patterns and returned to its natal territory, would be attacked by one or both parents. 
The juvenal ${ }^{1}$ pattern probably also decreases aggression as the juvenile wanders in late autumn and through the next year (Crane and Nellist 1999). It may be hastened from a territory by the resident adults, but it is unlikely to be attacked in earnest or killed.

\section{Functions of Plumage Coloration}

Pied Plumage. Why is the boldly contrasting plumage of the juvenile Golden Eagle so different from that of all other juvenile eagles in the genus Aquila? The general trend in the order Falconiformes is for juvenal plumages to be more "cryptic" than later plumages. It is beyond the scope of this paper to explore this issue in depth, but it is probably no mere coincidence that the juvenile Golden Eagle and the adult Black Eagle ( $A$. verreauxii) are both boldly (although differently) marked "black" and white. From examination of museum specimens, these two species and the Wedge-tailed Eagle (A. audax) are the largest and the most powerfully equipped (largest feet and talons) of the genus. As such, they are the species most capable of killing territorial intruders. These two species are also the Aquila eagles that are most likely to breed on large cliffs in open habitat, where a single cliff is likely to be the only attractive nesting site for great distances. Juvenile Wedge-tailed Eagles, by contrast, lack the bold black and white plumage and this species is almost exclusively a tree nester (Watson 1997). Inasmuch as wandering juveniles would also be attracted to such sites (and thereby incur attacks by resident adults), a protective mechanism, conspicuously non-adult plumage, would be adaptive.

That the pied juvenal plumage of the Golden Eagle is protective has yet to be demonstrated statistically. However, my own observations, mostly from blinds and from Montana (Ellis 1979:37-38, pers. observ.), together with two decades of general observation (and therefore with a less obstructed view of aerial interactions) by Crane and Nellist (1999:108) strongly suggest that intruding juveniles are tolerated more than interloping adults.

Further, that pied plumage is so conspicuous in the Golden Eagle juvenile suggests that protection

\footnotetext{
${ }^{1}$ Exclusive meanings for terms: juvenile (a bird from fledging until onset of molt nearly 1 yr later), juvenal (plumage of the juvenile), immature (bird or plumage from 1-2 yr of age), subadult (a bird or plumage from $2 \mathrm{yr}$ of age until all plumage is adult-like), adult (bird or plumage achieved with the loss of the last subadult [i.e., extensively white] remex or rectrix - normally this loss occurs at about 5 yr of age [Bloom and Clark 2001]).
}

from adult eagles is more important for survival than being cryptic to potential predators. However, neither the Black Eagle nor the juvenile Golden Eagle, when in head-on pursuit of prey, presents the bold white patches so evident when viewed from the back, overhead, or beneath.

The Need for Dark Pigment. Although the juvenile Golden Eagle has extensive white zones (i.e., presumed sign stimuli) in the wing and tail, the disadvantages of white plumage in sunny climates have been known for decades, if not centuries; Bent (1921:150) and Averill (1923) noted that white areas on primary tips in gulls (Laridae) become much more heavily worn than adjacent dark areas. Burtt (1979) and Bonser (1995) documented experimentally that dark pigment reduced abrasive wear to feathers. Barrowclough and Sibley (1980) reported that white remiges of a partially albino wood-warbler (Parulidae) showed much greater wear than adjacent, normally-pigmented feathers. Inasmuch as aberrant white feathers (sometimes or always) also show structural imperfections (Chandler 1916:279, Sage 1962:219), a natural experiment would be the comparison of wear patterns between light and dark areas on normal feathers. Figure 1 (a and e) is just such an experiment. Golden Eagle feathers demonstrate that heavily-pigmented zones wear better than pale.

Although Burtt (1979) concluded that natural feather wear was due largely to abrasion from collisions with dust particles, the locations of the wear zones in the wing in Fig. 1d, and the lack of wear in the pale zones in remiges in Fig. 1b, indicate that the preponderance of wear occurred not during flight, but while the birds were perched with tail and wings folded. Burtt (1986:37) stated that, "Feathers are nonliving structures that are not seriously damaged by ultraviolet radiation....", However, the bleaching and fraying evident in Fig. 1d apparently occurred when the wings were folded. As such, this damage is not due to collision with dust during flight. In primaries of both species, the tip of the next proximal primary was photographically etched on its distal neighbor. This corroborates the hypothesis that the source of damage is insolation, which perhaps works synergistically with other weather factors such as repeated cycles of wetting and drying.

Evidence for nonabrasive wear includes Test's (1940) brief trials (65 d), wherein carotenoids in woodpecker (Picidae) feathers faded more quickly 

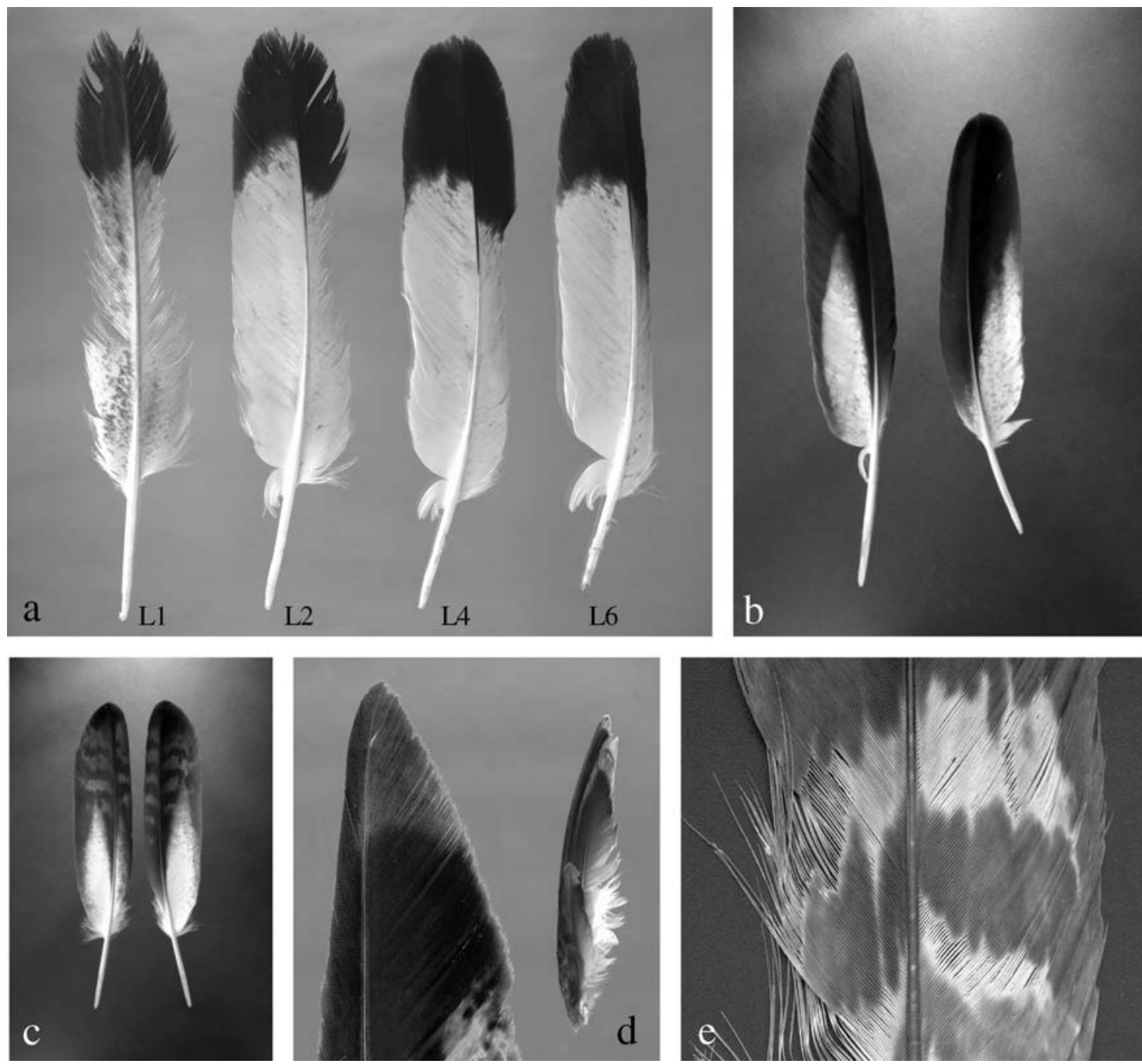

Figure 1. Bleaching and fraying of feathers. (a) Representative tail feathers of an immature female Golden Eagle (collected during late summer 2000 near Flagstaff, Arizona, U.S.A. hatched spring 1999). Tail shows extensive degradation in pale areas, especially of the central rectrix (L1). Rectrices are numbered 1-6 beginning with the central feather. (b) Remiges from this same bird show that light areas, hidden from the sun in the folded wing, did not wear as did the tail. (c) Second generation primaries molted in 1975 from a female eagle (feathers grew in 1974; eagle hatched in 1973, Montana U.S.A.) show that considerable white is retained after the first molt. (d) Left, sunprint (a "natural photograph") of the next proximal primary on primary no. 4 (feather molted 1998, adult female, southeastern Mongolia). Right, even clearer examples of sunprints on the distal primaries of an Ancient Murrelet (Synthliboramphus antiquus; June 1993, Langara Island, Queen Charlotte Islands, British Columbia, Canada). Wear patterns in both photographs show that damage occurred when the wings were folded. (e) Extreme bleaching and fraying in pale "bars" on a molted central feather of an adult female Golden Eagle (1998, central Mongolia).

than did melanins. Although Test ascribed this bleaching to the sun, his feathers were also exposed to heat, rain, and wind, so the results were confounded. Bergman (1982) concluded that the dark pigmentation on gull wings provided solar protection.
To test for solar wear, I conducted an experiment with identically-colored secondary remiges from the same wing of a recently-fledged juvenile Golden Eagle (shooting mortality). One feather (SUN) was placed dorsal surface up in full sun in a glass 
chamber. A second feather (SHADE) was placed in the same chamber but was hidden from direct sunlight beneath a shelf. It was, however, subjected to scattered light. A third feather (DARK) was placed in a completely darkened cabinet and removed only for periodic comparisons with the other feathers. At $60 \mathrm{~d}$, the dorsal surface of SUN was slightly bleached. At $106 \mathrm{~d}$, SUN was clearly paler than SHADE. At $125 \mathrm{~d}$, SUN was conspicuously lighter than SHADE, but also SHADE was slightly paler than DARK. At $165 \mathrm{~d}$, SUN and SHADE were both bleached dorsally, but only SUN ventrally. At $230 \mathrm{~d}$, SHADE was still only slightly bleached and only dorsally. SUN was very faded above and slightly faded below. At $282 \mathrm{~d}$, the experiment was terminated. SUN was substantially faded on top and bottom, and pale areas on the feather were frayed. SHADE was still only slightly bleached above and below. The bleaching obtained in this experiment, although like that seen in molted feathers, resulted from only a portion of the sunlight spectrum (i.e., the window pane glass used absorbs all wave lengths below $320 \mathrm{~nm}$ and reduces the intensity of UV radiation between 320 and $400 \mathrm{~nm}$ [E. Burtt, Jr. pers. comm.]).

In less controlled experiments, more rapid wear was evident when feathers were suspended aloft, exposed to wind, rain, and sun. Further observations were made on the plumage of captive eagles, which were allowed only minimal opportunities to fly (i.e., within their pens), but were exposed extensively to the sun and storms. The plumage of these birds showed fading and fraying like that observed in feathers molted by wild eagles and observed in museum specimens.

The disparity between conclusions from simple experiments by Test (1940) and me and Burtt's extensive experimentation is somewhat resolved by recognizing that heavy pigmentation, even though it may function primarily as protection from solar wear, also makes feathers more resistant to abrasion as Burtt $(1979,1986)$ demonstrated. In a similar vein, melanic feathers are more resistant to natural abrasion from the substrate, from rough vegetation, and from sandstorms. Other possible advantages of dark plumage are discussed by Cott (1966), Voitkevich (1966), Burtt (1979, 1986:95-96, 1999), Walsberg (1983), Burtt and Ichida (1999), and Roulin et al. (2001). Dark pigment also better resists mite damage (Moyer and Clayton 2004) and retards bacterial degradation of feathers (Goldstein et al. 2004, Shawkey and Hill 2004). However, as discussed by Burtt and Ichida (1999), keratophilic bacteria were important only in the high humidity conditions of the ventral body feathers of small passerines. As such, bacterial damage seems inconsistent with the wear patterns I observed in the flight feathers of Golden Eagles.

My approach in this paper was to find subtle pigmentation traits in white zones in juvenile Golden Eagle plumage, then see if these trends were amplified in older (i.e., less white) Golden Eagles. Thereafter, I compare traits in a broad spectrum of raptors, all this toward identifying traits that are potentially adaptive.

My search for protective traits in raptor plumage obviates the criticism justly leveled at many studies of avian pigmentation (Cuthill et al. 2000). Briefly, because some birds are now known to see colors in the ultraviolet range, it is important, in interpreting plumage features, especially those with likely social function, to see the feathers as the bird sees them. From inspection of feather damage due to natural wear (e.g., Fig. 1a, d, e), I am, in effect, avoiding the pitfall of trying to see the feathers the way birds see them. I examine them on the basis of how extensively they are damaged in normal use.

I found little in the literature providing similar detail on protective color features for individual feathers. Neither Chandler (1916), nor Cott (1966), nor Lucas and Stettenheim (1972) provide much on the function of the shape and color features they report. The most detailed treatise to date is Burtt's (1986) monograph focusing on the function of melanin in the plumage of wood-warblers.

Why Focus on the Juvenal Plumage of the Golden Eagle? Some may suggest that with the great variability found in the plumage of Golden Eagles (Fig. 2), that this species would be a poor model for searching for adaptive plumage traits. This eagle exceeds, at least in subtle plumage features, the hyper-variability exhibited by the Ruff (Philomachus pugnax). The degree of diversity in bars, flecks, spots, and streaks within even a single individual approaches infinity. These patterns are so complex that a single feather follicle cannot reproduce the same pattern from year to year even in the adult (pers. obs.). As stated by Jollie (1947:549), "This plumage variability has puzzled taxonomists more, perhaps, than that of any other species of bird...." Because of this variation and because those who have already tried to explain it have had such limited success (e.g., Jollie 1947, Tjernberg 

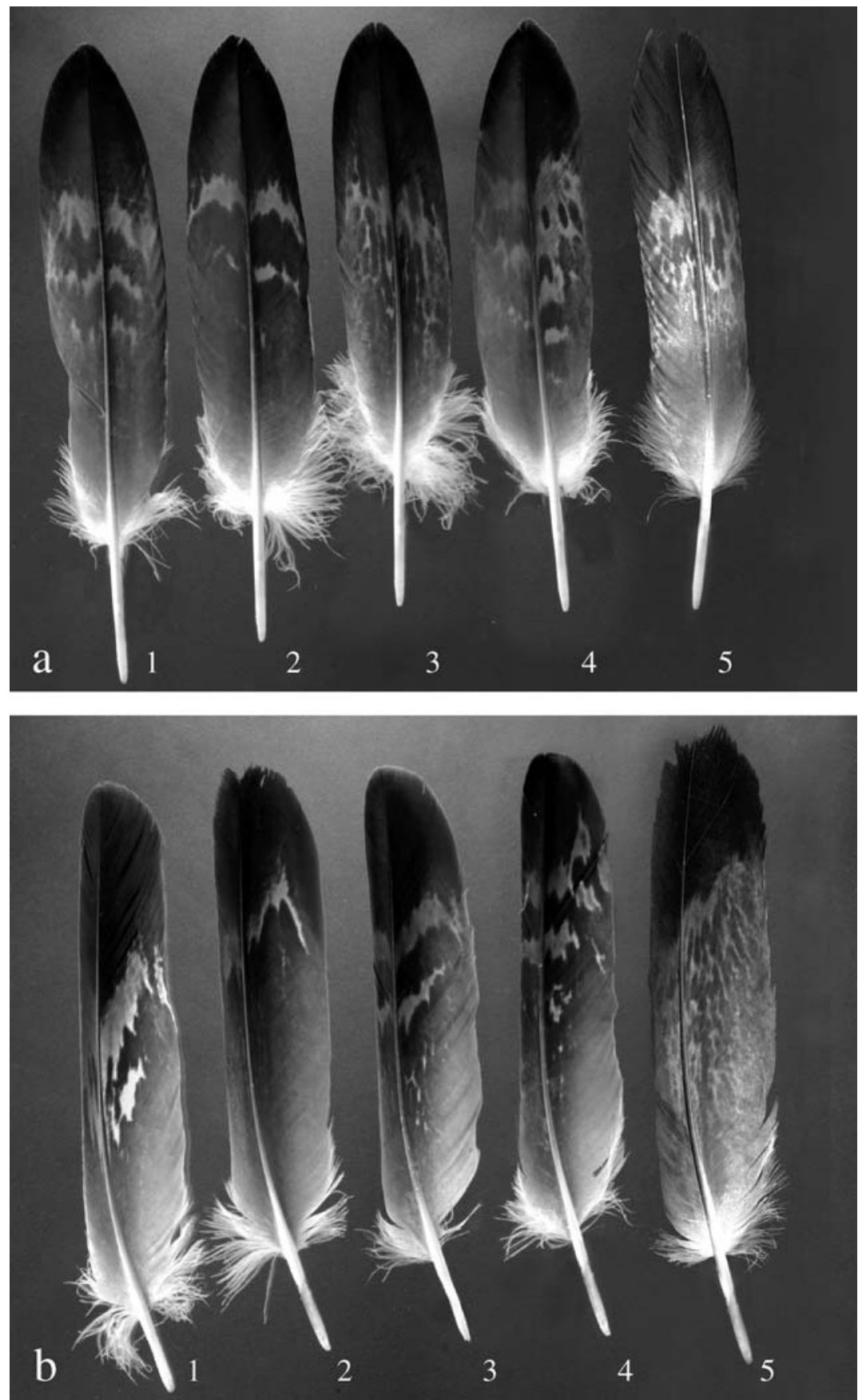

Figure 2. Variety in color patterns for rectrices in adult Golden Eagles: (a) central feathers showing barred, spotted, and streaked patterns (1-4 Montana, 5 Scotland), and (b) lateral rectrices (1-4 are R6, 5 is R5) showing two diagonal bars (1), single bar (2), complete and disrupted cross bars (3 and 4), and vermiculation (5). Numbers 1 and 5 are from Mongolia, 2-4 from Montana. 
1977, Clark and Wheeler 1983, Palmer 1988, Bloom and Clark 2001), it is with some trepidation that I make this attempt. However, my approach is different: the other papers emphasize the degree of variation with no treatment of functional morphology. By contrast, I sort through the variation to identify common features that suggest the possibility of adaptive function.

Perhaps, the first place to search for adaptive traits is in the white patches on the juvenile wing and the base of the tail where pigment appears to be strategically placed to minimize wear. Even though the possible permutations in plumage pattern even in the juvenile tail are indeed infinite, there are a dozen or so consistent trends that will surface to guide us through the morass.

The logic that follows is based on three premises: first, that melanin strengthens feathers and prolongs their useful life (Burtt 1986); second, that variably-expressed traits common to a variety of species are usually adaptive (Hailman 1976); and, third, that the bold black and white plumage of the juvenile Golden Eagle presents sign stimuli that allay adult aggression (see section on Pied Plumage). I view the pied plumage of the juvenile to be the best compromise between three conflicting selective pressures. First, to survive as a predator, the juvenile must not be so conspicuous as to warn its prey. Second, the strong black and white pattern is essential in protecting young eagles from attacks by territorial adults. Finally, the juvenile must protect the white zones from solar and abrasive wear by supplying pigment where it is most needed. Because of these three conflicting conditions and because individual wing and tail feathers are routinely retained for 2 and often $3 \mathrm{yr}$ (Jollie 1947, Clark and Wheeler 1983, Bloom and Clark 2001, Ellis and Kéry 2004), the Golden Eagle is the species most likely to provide a key in deciphering feather protection rules.

Function of the Pale Tip. The pigmentation pattern of the juvenile tail, although simple when viewed from afar (frontispiece), is, upon closer inspection, very complex. First, the black band is not terminal; rather it subtends a pale tip (Fig. 3). In considering the adaptive value of the pale terminus, I acknowledge that much of what is observed in nature is the result of developmental constraints. In this case, the light tip may be an ontogenetic artifact, a transition from the white down of the chick. Pre-pennaceous down is actually the terminus of the emerging contour feather
(Watson 1963, Voitkevich 1966:2). Note the downy remnants visible on the tips of many rectrix barbs in Fig. 3a, b, not just on the tips of the rachi. That this pale tip probably has little or no social function can be deduced from its inconspicuous nature in some fledglings and its absence (having been worn off) in many winter juveniles and more yearlings (e.g., Figs. 1a and $3 \mathrm{c}$ right). If this terminal white tip were of great importance as a social signal, it should have been more strongly favored by natural selection and more conspicuously displayed by all juveniles (at least in migratory populations, wherein peregrinating juveniles must pass through the territories of many bellicose adults).

A second likely benefit of the pale tip, and this is the explanation I favor, is that less pigmentation, seemingly in contradiction to what I have presented so far, actually promotes feather longevity. The less pigmented light tip is, by inspection if not by experimentation (pers. observ. and E. Burtt, Jr. pers. comm.), more flexible than nearby dark areas and thereby less likely to break on contact with hard surfaces. The terminus, if stiffened by melanin, would be better protected from bleaching and minor abrasion, but more likely to break as the chick bounds about the nest and jams its tail into the nest during mock predation, important developmental activities prior to fledging (Ellis 1979:35-37, 69-70), and during predation after fledging.

More evidence for the importance of the pale tip comes from noting the sizes of the pale spots at various rectrix loci. If the spots were adaptive in promoting flexibility and limiting breakage, they should be largest in the zone subject to the greatest trauma. In Figs. 1a, 4a, and c, the bulk of the breakage is near the center of the tail. The rectrices in Fig. 4c have (or had before breakage) larger pale spots proceeding toward the central rectrices (centrals). This trend is evident in other fresh tails examined, but in heavily worn tails (such as in Figs. 1a and 4a), the pale spot is often entirely eroded away.

Birds in other avian orders do not always follow the same strategy in preserving rectrix tips. For woodpeckers, swifts (Apodidae), and some other groups in which the tail tip routinely supports much of the mass of the bird, the tip is not pale, as in the Golden Eagle, but is dark, attenuated, and the rachis tip is enlarged to resist erosion.

Protecting White in the Wing. When perched (and not sunning), juvenile Golden Eagles show no 

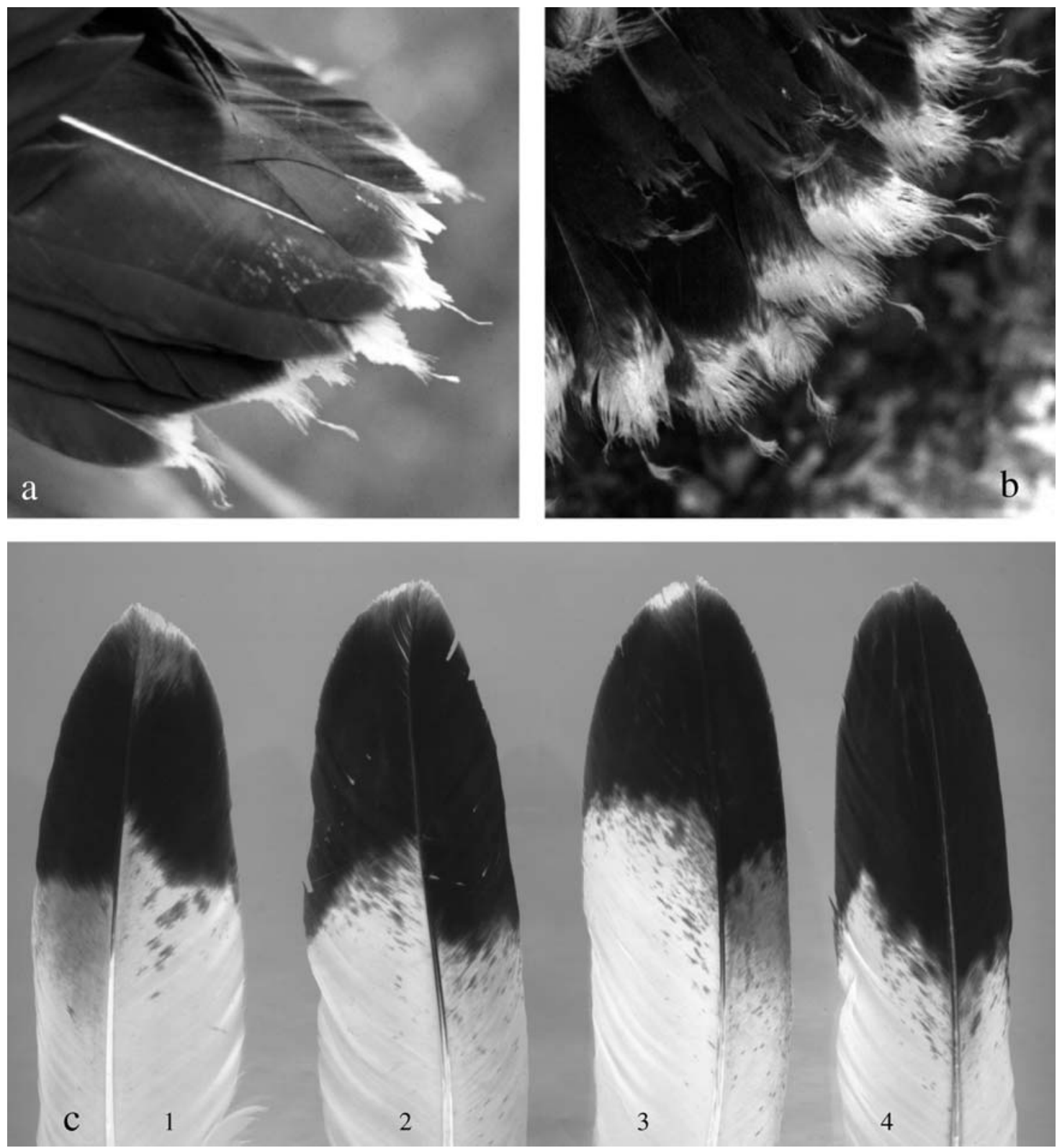

Figure 3. Variations in white rectrix tips: (a) tail condition in a fledgling with an unusually long protruding white tip (age ca. $70 \mathrm{~d}$, Montana, 2 July 1971), (b) normal condition in a nestling (ca. $50 \mathrm{~d}$ of age, central Mongolia, 19 June 2000), and (c) tail tip condition in four juveniles after several months of wear (all birds western U.S.A.).

white in the remiges. However, white in the tail remains conspicuous and thereby may function as a sign stimulus. But the result of having white always show in the tail is that, through time, the tail undergoes conspicuous bleaching and fraying (Fig. 1a). White in the wing, by contrast, shows little or no wear (Fig. 1b). Justification for sacrificing the tail rather than the wing seems logical when examining the extent of wear normal in the tail (Fig. 1a). Flapping flight is probably little hampered by a few extensively eroded rectrices, but remiges are essential in propelling the bird forward and 

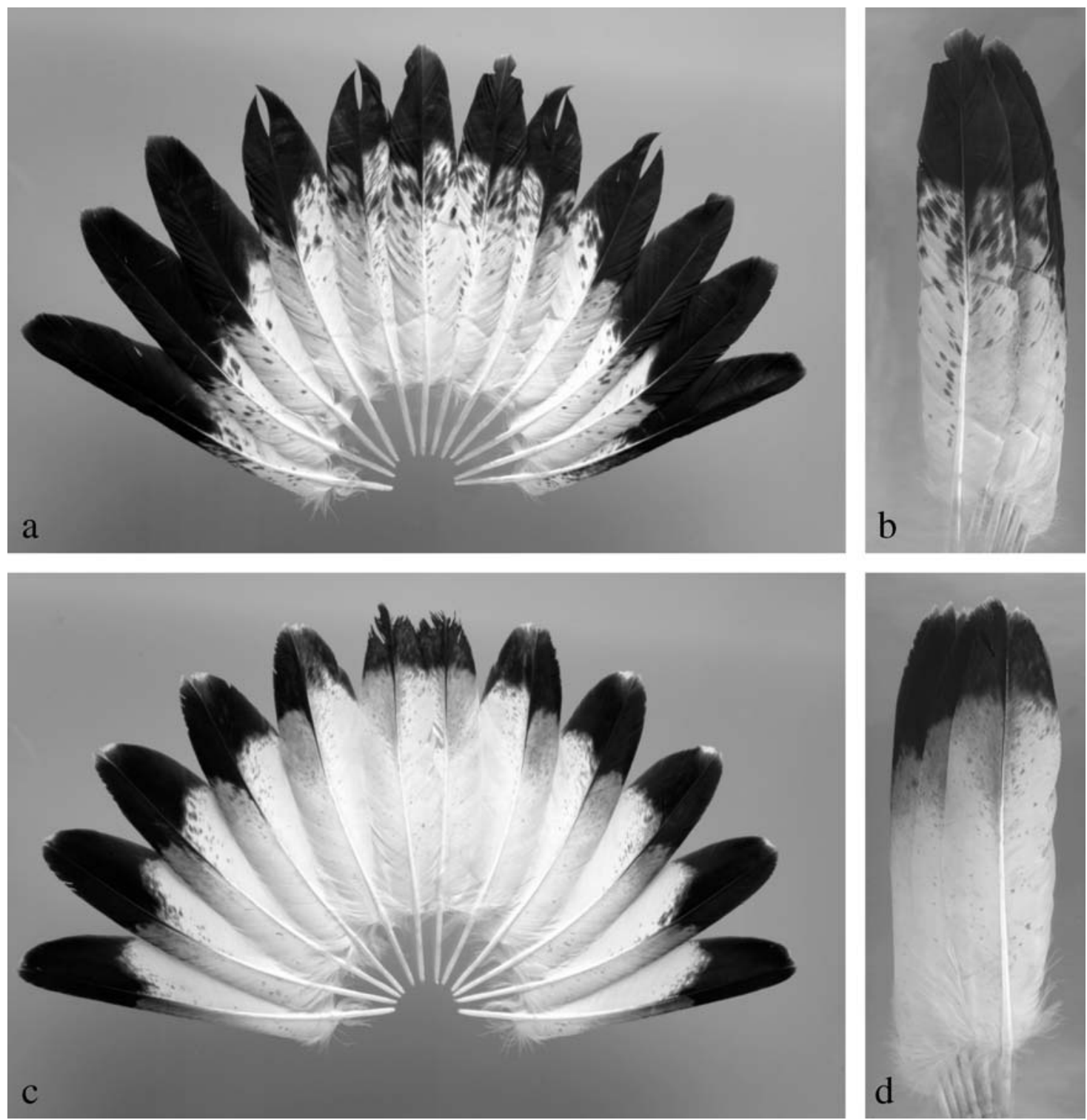

Figure 4. Juvenile tails showing extent of white zone (both birds from Montana). (a, b) Fanned tail and folded half-tail, respectively, of bird with extremely broad dark band (female hatched 1973; feathers were molted in 1974 and 1975). (c, d) Fanned and folded half-tail, respectively, of bird with narrow dark band (powerline mortality, April 1974, male hatched 1973). The extent of the white zones, although different on fanned tails (a, c), are more similar on folded tails $(b, d)$.

providing lift. Heavy erosion here would significantly impair flight efficiency (Tucker 1991, Thomas 1993, Swaddle et al. 1996, Hedenström and Sunada 1999).

Evidence that white in the tail is of greater importance than white in the wing comes from the observation that, although some juveniles have very little white in the wings, these same birds have an extensive white zone in the tail (Watson 1997:210, Bloom and Clark 2001:113). Continuing with this logic, even those juveniles with very dark tails (compare Figs. 4a and c) have an extensive white 

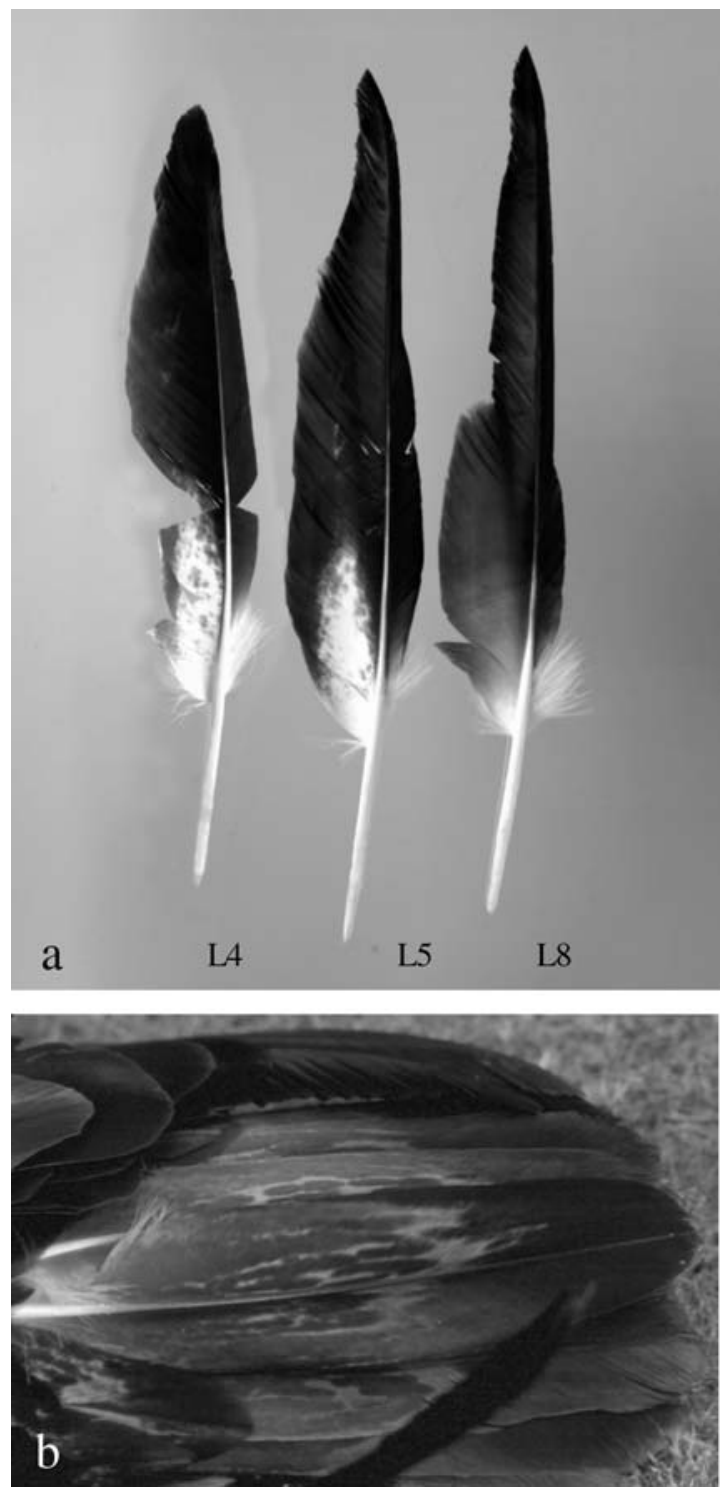

Figure 5. Two features that protect feathers at key loci. (a) Fault bars (molted juvenal feathers from female hatched 1973, Montana) are more extensive in proximal primaries (Nos. 4 and 5) than in more distal (No. 8) primary. Unnatural bending of feather tips (L5 and L8) occurred during storage and were not the result of natural wear. (b) The central feathers extensively overlap when tail is folded (living adult female from Montana).

zone visible even when the tail is folded (compare Figs. $4 \mathrm{~b}$ and d).

A different sort of evidence supporting the idea that the eagle sacrifices the tail before the wing comes from mapping the locations of fault bars (narrow creases crossing the feathers diagonally left and right from the rachis coinciding with days that the nestling was without food or physiologically stressed [Grubb 1989]). Fault bars are conspicuous in the plumage of many juveniles and inconspicuous, but present, in all other juvenile eagles I have examined. Three fault bars are evident on L1 in Fig. 4a. In most eagles, bars are not severe. Severe bars can result in severed barbs (Fig. 4a: tip of L1). If even more severe, the rachis breaks at the fault bar or the feather is cast while still growing.

Fault bars affecting one or a few feathers probably reflect a temporary restriction of blood flow to a small area. Broad scale fault bars (i.e., those evident at the same location in a series of simultaneously growing feathers) in wild nestlings probably reflect an interval of acute stress (King and Murphy 1984). Using an extensive bar, it is possible to compare the degree of damage across the wing and tail (Figs. 4a, b, 5a). The slotted primary (Fig. 5a: L8) and other primaries along the leading edge of the wing showed much less damage than the inner primaries (e.g., Fig. 5a: L4 and L5). Secondaries (not illustrated) showed the least damage. Rectrices (especially at mid-tail) showed the greatest damage due to fault bars.

If, as this bird's plumage (Fig. 5a) suggests, young eagles are physiologically able to control, to some degree, the location and severity of fault bars, quantitative data for many birds will likely show that fault bars are least prominent in feathers most needed to sustain flight. Based on the juvenile in Figs. $4 \mathrm{a}$ and $5 \mathrm{a}$, the most important to least important feathers are the margin of the wing (primary loci 8-10) and the secondaries, the inner primaries (loci 1-5), the margin of the tail, and finally, the remainder of the tail. This order is consistent with the experimental design used by Swaddle et al. (1996) and the models developed by Hedenström and Sunada (1999). This pattern is generally congruent with data for captive Whitecrowned Sparrows (Zonotrichia leucophrys; King and Murphy 1984). If the bar location trends hold true for other eaglets, this provides further evidence for the importance of protecting the wing over the tail.

Protecting the Tail. There are many features of the tail that promote feather longevity, while leaving an extensive white patch visible in both the folded and the fanned tail (Fig. 4). Similar to the blacktipped primaries on gulls (Larus spp.; Averill 1923), 

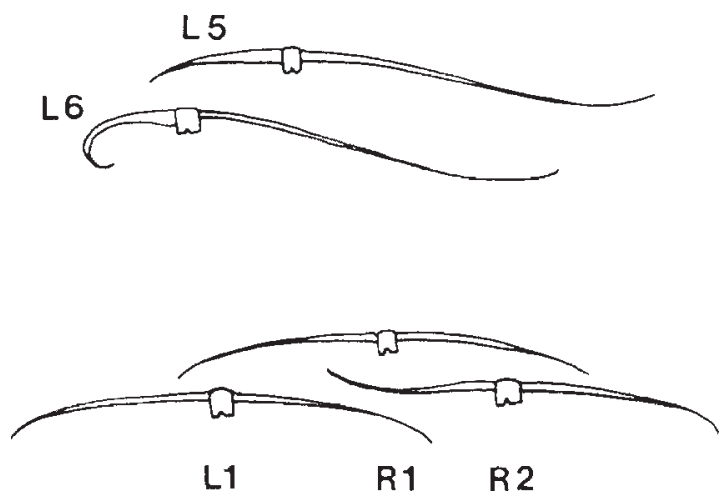

Figure 6. Schematic cross sections of rectrices at loci 5 and 6 (top drawing) show features that strengthen the side of the tail (i.e., outer web on L6 is narrow and curls under the tail; also barbs here are deeper). The central feathers (bottom drawing), unlike any other rectrices, have both inner and outer webs down curved. For R2, by contrast, the inner web curves upward.

the eagle's black tail band likely also limits some kinds of wear. In the folded tail (Figs. 4b and d), most of the visible white is on the central feathers. Because the centrals degrade so extensively (Fig. 1a), the Golden Eagle has several compensatory mechanisms.

Two feathers at central position. The foremost protective measure for the tail is that the bird has overlapping central feathers. In the folded tail (Fig. 5b), one central covers most of the other. They also "take turns" at the top position (unpubl. data), but even if they did not, the lower feather would assume more and more wear as the upper feather disintegrated.

Vane shape shows that both centrals are designed to lie on top (Fig. 6: L1 and R1). For rectrices 2-6, the margin of the inner web (medial web) curves upward, becomes very flexible, and terminates in a slight fringe (frayed effect). The outer web (at all loci), by contrast, curves downward, is stiffer, and has no fringe (Fig. 6). Both webs of the centrals have all the features for outer webs: both webs are designed to lie on top.

Pigmentation of most centrals also demonstrates that both are designed to lie on top. In Figs. 1, 3, and 4, note that for loci 2-6 the black band is wider on the outer, more insolated, web than on the inner, more protected web. By contrast, for the centrals, the band on the inner web is as extensive, or nearly so, as it is on the outer web (Fig. 4). Also, in the white zone on these tails, dark pigment

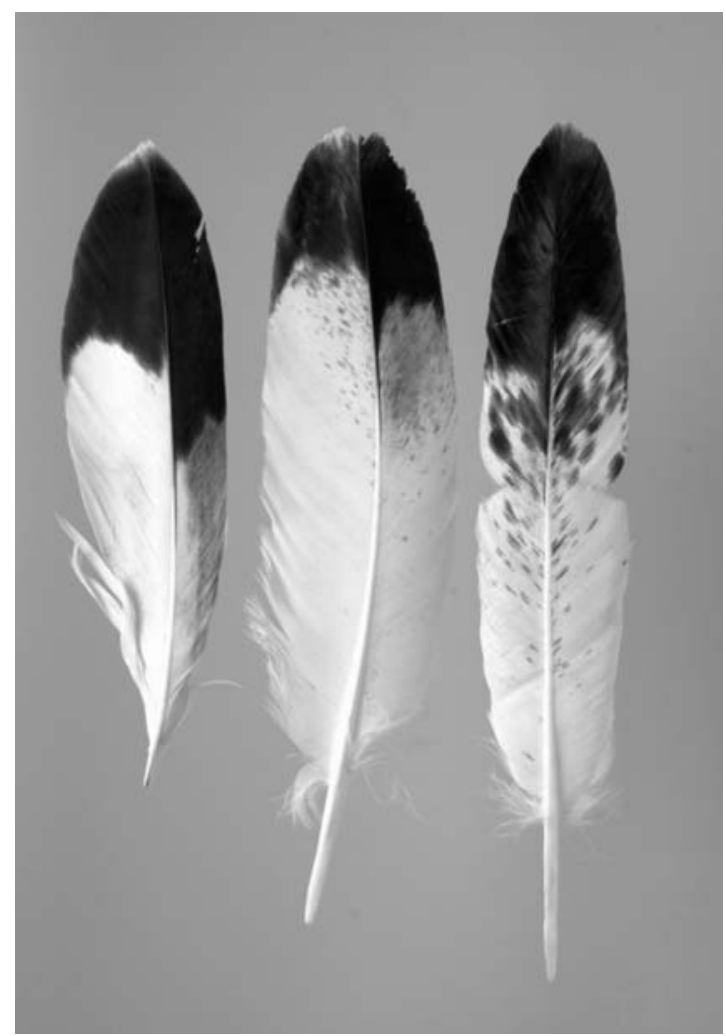

Figure 7. Pigmentation classes in white zones of juvenile rectrices. Left, heavy gray wash on outer web (partially grown feather [L5] from dead fledgling found below eyrie in central Mongolia, hatch year 1997, feather recovered 7 July 1998). Middle, flecking (and some gray wash [L2]; male hatched 1973, found electrocuted April 1974, Montana). Right, bold blotching (with little or no gray wash [R1]; female hatched 1973, Montana, molted feather).

extends basally as a grayish wash or as blackish flecks or blotches (Figs. 3c and 7). At loci 2-6, dark pigmentation is much more extensive on the outer (solar exposed) webs than on the inner webs (Fig. 4). For the centrals, by contrast, pigmentation is equally heavy, or nearly so, on both webs (Figs. 1a, $2 a$, and $4 a$ ). Both webs of the central feathers are also darker, not only in juveniles, but also in immatures (Fig. 8a), and even in older birds (Fig. 8b). Consistent with the pigmentation trends on the centrals, both webs of the longest scapulars and tertials (which also have both webs exposed to the sun) are also similarly pigmented. At all tail loci, the dark pigment (wash, fleck, or blotch) is supplied more abundantly near the black subterminal band (Figs. 3, 4, and 7). 
Lateral rectrices are darkest and shaped differently. The most heavily pigmented rectrix webs are not on the centrals (where solar wear is most conspicuous; Fig. 1a) but rather on the outer webs of the lateral rectrices (Figs. 1a, 4a, and d). Laterals are, more than any other rectrices, hidden from the sun in the folded tail (Figs. 4b, d, and 5b), yet they project most into the airstream during some flight activities. Like the lateral rectrices, the outermost primaries (Nos. L10 and R10) also project most into the air stream and also have the darkest outer vane of all primaries. This is the only primary vane for which, even in very pale eagles, I have never seen a white outer web.

Lateral rectrices also show shape differences. In Figs. 1a, $4 \mathrm{a}$, and $\mathrm{c}$, the outer webs at loci 6 are only about one-fifth as wide as the inner webs. This places the margin of the tail near the stiff, supportive rachis. The barbs of the outer vanes at loci 6 are also deeper (Fig. 6) and the basal half of the outer vane also curls under the tail, turning more than $180^{\circ}$ as it does so. These features stiffen the outer margin on the outer vane beyond that of any other vane on any other rectrix. As such, they should promote flight stability. Interestingly, all of these features are also present on the leading edge of the wing (Chandler 1916:265, Montalenti 1934). Finally, the calami of rectrices No. 6 are also shorter and deeper (i.e., the dorsal to ventral diameter is greater), and therefore stronger than for other rectrices (inconspicuously evident in Fig. 8a).

Dark on or bordering the rachis. In the white zone, the rachis or the vane adjacent to the rachis is extensively dark. Thereby the vane is presumably strengthened and more firmly attached to the rachis. Either the dark on the central ridge of the rachis extends into the white zone (Fig. 9a) or the central ridge of the rachis is white, but narrow stripes of black along the sides of the rachis extend into the white zone (Fig. 9b). Alternately, the barbs are dark basally, so that a thin line of black extends along each side of the rachis far into the white zone (Fig. 9c). Finally, diffuse streaks of gray sometimes extend basally far down the dorsal surface of the rachis (Fig. 9d).

Dark along the margins of each feather. In most juveniles, the black zone normally extends basally further along the inner margin of each juvenile rectrix than it does elsewhere on the inner web (Fig. 10a). To some extent, this also appears on the outer web (Figs. 1a: L6 and 10a). Black tips on many otherwise white barbs should have the same strengthening effect as the black spot on the gull primary. For heavily bleached feathers, the pale portions of the vane remain intact longer if the area is protected by dark-tipped barbs (Fig. 1e). This trait results in the white zone of the juvenile tail being ringed with a protective dark border when the tail is fanned, even for pale birds (Fig. 4c). In the adult (Figs. 10b-c, 2, and 8b), there is often a conspicuously darker border on the margin of both webs, especially on the centrals. This trait is amplified in the wing where the white zones are often extensively bordered with dark (Fig. 1b, c).

The Rule of Diminished Extremes. In feather series (e.g., the primary flight feathers), wherein the terminal feather protrudes (inviting either abrasive wear or heavy resistance in the airstream), the last feather (and sometimes its neighbor[s]) is (are) often shorter than would be expected considering the trend within the series. It is as though this feather must be stabilized by some means, and this may be accomplished by shortening the extreme feather, so that the penultimate feather shares more of the stress (Fig. 11).

Some examples: The caudal-most scapular is shorter in the Golden Eagle (Fig. 11a). This species exhibits this "rule of diminished extremes" in several feather series, but clearer examples come from other species. In the Peregrine Falcon (Falco peregrinus), among the most pointed-winged of raptors, primary 10 is shorter, allowing primary 9 to share the stress of cutting into the wind (Fig. 11b; see Sundevall 1886). The outer primary is longest only among birds that capture and consume prey while aloft (e.g., swifts [Apodidae]) or capture prey in water (e.g., terns [Sterna spp.]), both foraging niches involve little abrasive wear. A final example of this rule is the shortening of rectrix 6 (Fig. 11c) in the most square-tailed of all North American raptors, the Sharp-shinned Hawk (Accipiter striatus).

\section{Plumage Changes with Maturation}

Juvenile remiges and rectrices are longer than those of later plumages (Fig. 12). Longer feathers result in lighter wing-loading, which would make juveniles more buoyant and facilitate soaring and migration (Amadon 1980). Longer feathers would also compensate for higher rates of breakage and wear among inexperienced juveniles. Some observations suggest that juveniles are more adept at rising on thermals, and therefore, better able to flee from territorial birds by soaring above the more heavily wing-loaded adults (pers. observ., Dekker 1999:138). 

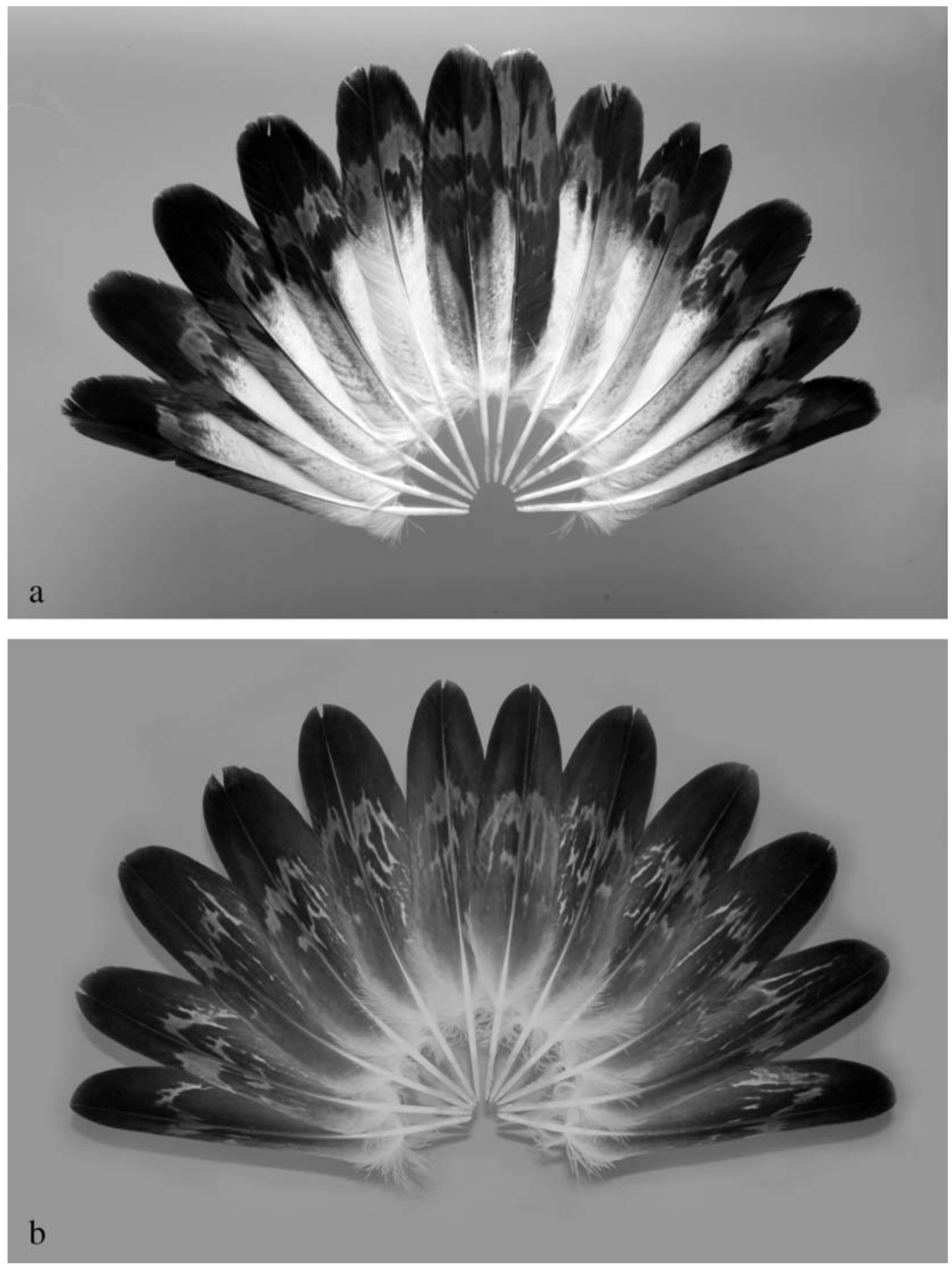

Figure 8. Deeper pigmentation shows at loci 1 and 6 than for other loci: (a) an immature tail (all feathers are either replacements for juvenile feathers or are the next succeeding generation; female poisoned 1971, Montana), (b) an adult tail (ca. 20th generation, all feathers molted, female hatched ca. 1960, Montana). Note that white mottling is found only at Loci $2-6$ and only on inner webs. 

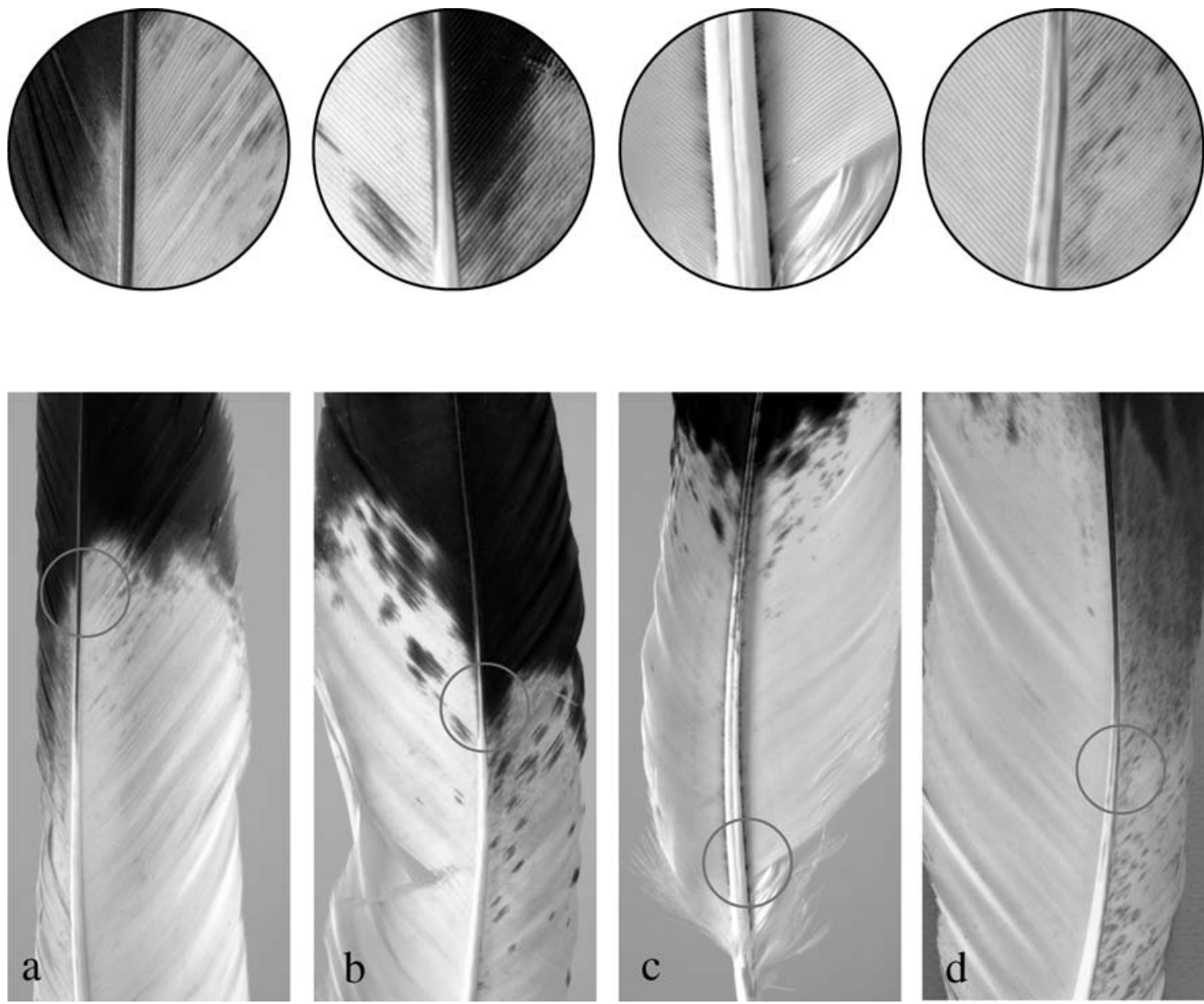

Figure 9. Four methods of darkening (strengthening) the zone along the rachis of juvenile feathers: (a) the rachis is extensively dark into the white zone (L5, Arizona); (b) the central ridge of the rachis is white, but lines of black extend basally along the sides of the rachis into the white zone (L3, Montana); (c) the seams joining the vanes to the rachis are extremely narrow lines of black extending far down the shaft (L4 or L5, Montana); and (d) wavy lines of gray pigment are scattered basally along the shaft (L3 or L4, Colorado).

If the dark pigmentation features listed earlier do promote feather longevity, then most or all of these traits should be magnified in succeeding feather generations. Specifically, as the bird matures, the centrals and the laterals should darken more and before other rectrices. Also, the outer webs and the shafts of all rectrices should darken sooner and more than other parts of these feathers.

A conspicuous feature of replacement feathers is the retention of much white in the tails of all birds (Figs. 8a and 13) and the wings of some (Fig. 1c). This white may be merely an ontogenic artifact; but immature birds, by displaying white, may also receive benefit by signaling their youth to adults, just as juvenal plumage remnants likely protect immature male Red-winged Blackbirds (Agelaius phoeniceus) from adult male aggression (Beletsky 1996:36).

In the Golden Eagle, dark juvenile traits are clearly amplified in subsequent plumages. The white zones in the centrals darken most (both inner and outer webs: Figs. $8 \mathrm{a}$ and 13a), as do the outer webs at loci 6 (Figs. 8a and 13b). Molt patterns also reveal the greater importance of feathers at the center and outer edge of the tail. In the yearling, loci 1 and 6 are the rectrices most frequently replaced in the first molt (Jollie 1947, Palmer 1988:182), and replacement rates at these loci are 

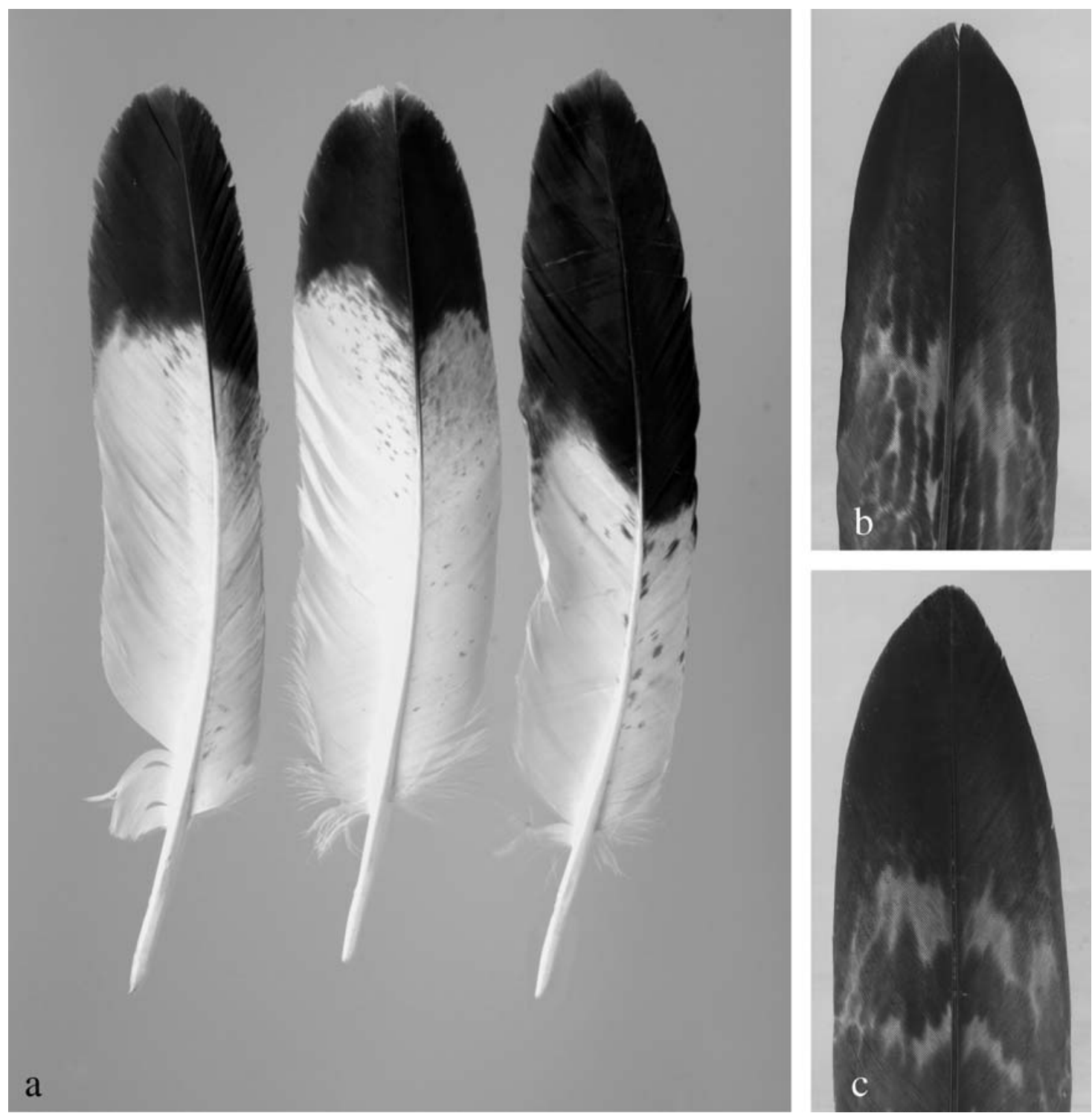

Figure 10. (a) The protective black band on these juvenile rectrices extends basally along the margin of the inner web. (b, c) Even in the adult, a band of much deeper pigmentation extends basally along both margins of these central rectrices (L1). (All birds are from Montana, except a left is from Arizona.)

higher even in the adult (Ellis and Kéry 2004). Also, those white areas that, in the juvenile tail, were most heavily washed with gray or flecked or blotched with black become more extensively pigmented in replacement feathers (compare Figs. 4a and c with $8 \mathrm{a}$ and 13). This is obvious for pigmentation on, and adjacent to, the rachi. The rule is for pigmentation to be heaviest in areas exposed to the sun in the folded tail. This principle is also evident in some adults (Fig. 8b), where the lightest (sometimes white) streaking is found only on the inner webs and only at loci 2-6. This rule, of course, does not apply to the pale basal areas hidden by tail coverts in life.

Curiously, in post-juvenal rectrices in many birds, the darkly pigmented subterminal band, although more extensive than in the juvenile, is often less color saturated, leaving the tip much paler and 


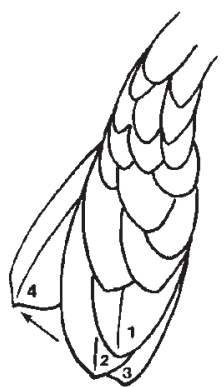

a
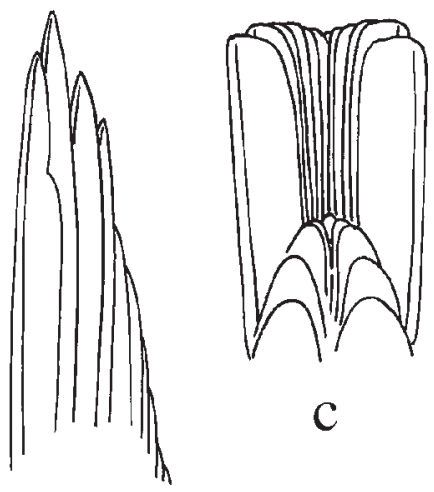

C b

Figure 11. Three feather groups, best examples of the rule of diminished extremes. (a) The caudal-most scapular (No. 4) of a Golden Eagle is shorter and hidden beneath more proximal feathers. (b) The outer primary (No. 10) of a Peregrine Falcon is shorter than the penultimate. (c) The outer rectrices of a Sharp-shinned Hawk protrude less than all others.

much more marbled (Figs. 8a [feathers L1 and R1] and 13a [feather 7]). There are likely some exceptions, but it is the norm for the pale marbling in immatures (and in some juveniles [Ellis 2004]) to be most prominent near the center of the tail (i.e., mostly at loci 1 , regularly at loci 2 and 3 , and seldom or never at loci 5 and 6 ). What seemed at first to be an anomaly (i.e., that post-juvenal rectrices are paler distally than they were in the juvenile) supports the hypothesis that the pale tip on the central region of the tail is adaptive (presumably in promoting flexibility and limiting breakage).

\section{Summary of Pigmentation Principles}

To review, there are a score of tail features that probably prolong feather life (Fig. 14). First, the protective black band (Fig. 14a) is actually subterminal (Fig. 14b). A terminal white tip may limit breakage. The pale tip is greatest near the center of the tail where most breakage occurs (Fig. 4a, c).

Next, there are several peculiarities of the central and outer rectrices. First, the centrals have a narrower black subterminal band (and therefore a wider white zone for social signaling; Fig. 14b). Second, the central feathers are modified to alternate in top position with both inner and outer vanes curving downward like the outer vanes on other feathers (Fig. 14e). Also centrals and laterals molt first (Palmer 1988) and more often (Ellis and Kéry 2004). The lateral rectrices have a deeper shaft and their outer vanes are narrower (Fig. 14c), deeper, and curl under the tail (Fig. 14d). To

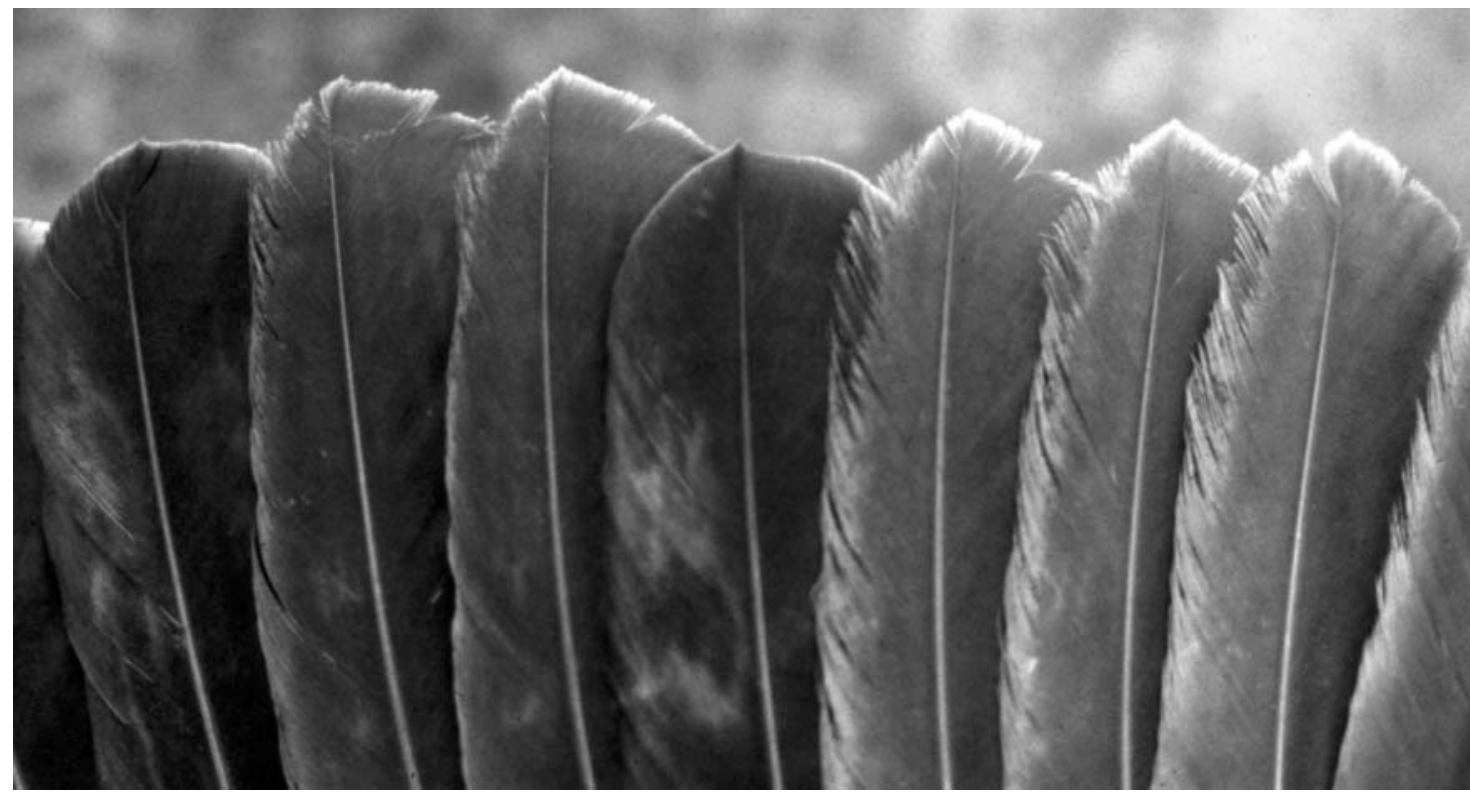

Figure 12. Secondaries on fanned wing of an immature male Golden Eagle (University of Arizona No. 16 250, electrocution, January 1991, Arizona) showing that juvenal secondaries (bleached and frayed) are longer than their replacements. 

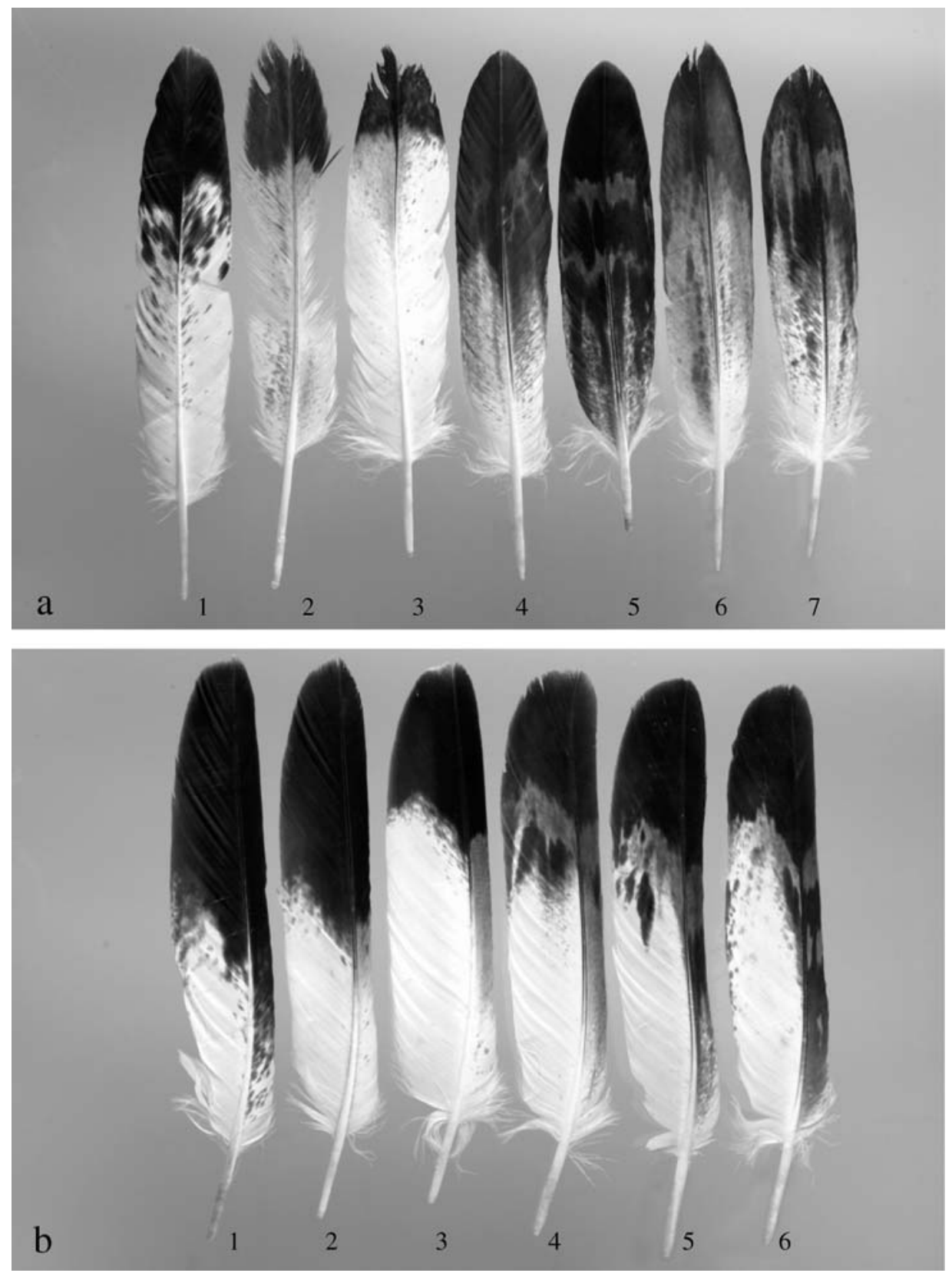

Figure 13. A comparison of rectrices at loci 1 and 6 showing that pigmentation trends in the juvenile are amplified in replacement feathers. (a) Centrals 1-3 are juvenal feathers, 4 and 5 are next generation feathers (4 replaced 1 in a captive bird); 5 is the still-growing replacement for the R1 feather which would have matched L1 illustrated here as No. 2; 6 and 7 are believed to be replacements of juvenal feathers but may be from the next generation. (b) Laterals 1-3 are juvenal, 1 and 2 represent the "broad band morph," 3 the narrow band morph; 4-6 are replacements from the next or following generations: their juvenile antecedents probably resembled 3. Note that in both a and b the later generation feathers differ from juvenal feathers by showing much more extensive dark pigmentation on the rachis, on the outer webs, and along the margins of both webs. (Feathers a1, a3-4, a6-7, b1-4, and b6 are from Montana, feathers a2 and a5 are from Arizona, b5 is from Colorado). 


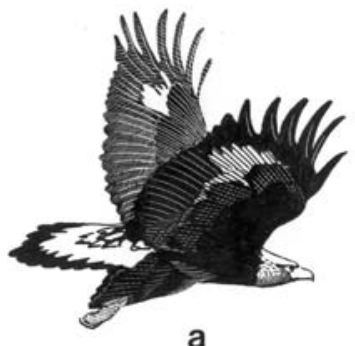

a
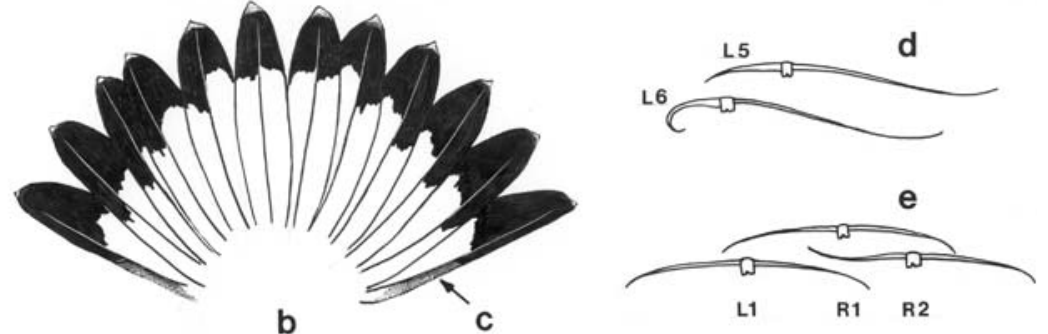

b
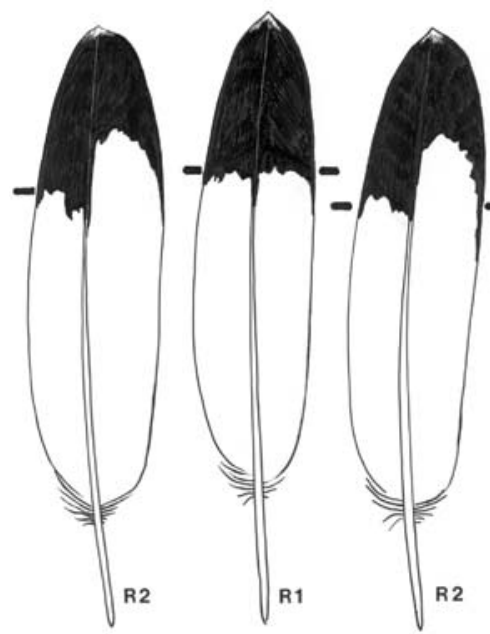

g
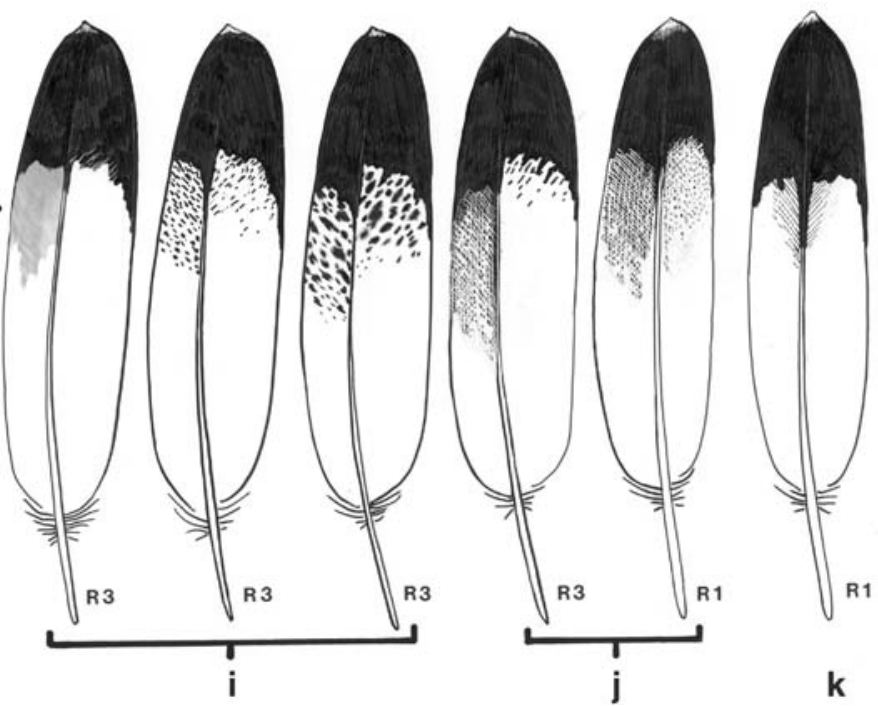

Figure 14. Schematic diagram of pigmentation and structural adaptations to strengthen or prevent breakage of the juvenile Golden Eagle tail. (a) The general black and white pattern on the juvenile tail is, upon closer inspection, much more complex. (b) The black "tip" is actually subterminal, with a terminal white or pale spot on each feather. Spots increase in size toward mid-tail. (c) The margin of the tail is dark. (d) The outer webs of the outer most rectrices are very narrow, rounded under, and thicker. (e) The centrals (L1 and R1), both of which are adapted to lie on top, have two outer-like webs (i.e., both webs are decurved). (f) The dark bands on feathers R2-R6 are asymmetric, being wider on the outer (more insolated) web of each feather. (g) On centrals, the dark band is nearly equal on inner and outer webs. (h) A dark line of pigment extends basally along the inner margin (and to a lesser degree the outer margin) of most feathers. (i) One or more of three patterns of pigmentation are normally present in the white base. These are a gray wash (left), black flecking (center), or black blotching (right). ( j) The dark pigmentation in the white zone is more pronounced on the outer webs at loci 2-6 but nearly equal on both webs of the centrals. (k) Dark pigmentation also extends basally along, or adjacent to, the rachis in most tails.

protect the white zone, the inner webs of the centrals (Fig. 14g, j, k) are pigmented like the outer sun-exposed webs of other rectrices (Fig. 14f, h, i).

For all tail loci, dark pigmentation extends basally along or on the rachis (Fig. 14f-k), along the inner margin of nearly all feathers (Fig. 14f-k), and along the outer margin of many feathers (Fig. 14f, h-k). Finally, there is a scattering of protective pigment (gray wash, black flecks, or black blotches; Fig. 14i) in the white zone. Changes in succeeding generations of feathers (Figs. 8 and 13) disproportionately amplify dark traits of the juvenal tail, thereby indicating the importance of each trait.

Comparisons with Other Species. If the traits identified in the Golden Eagle are adaptive, they should be evident to a degree in other species, especially those that (1) have white patches in wing or tail for social signaling, (2) dwell in open habitat, (3) occupy sunny climes, and (4) retain some feathers for more than one year. In the final figures (Figs. 15-17), 18 species, representing a broad spectrum of raptorial birds, were examined to 
determine if Golden Eagle traits were present. Selection of species was limited by the availability of specimens with disattached rectrices.

Many similarities with the Golden Eagle tail are noted (Table 1). In the adult male Rough-legged Hawk (Buteo lagopus; Fig. 15a), almost every Golden Eagle trait has its parallel. In particular, outer webs are darker than inner at loci 2-6, but not at loci 1. Even dark-tailed species (Figs. 15b-d, Crane Hawk [Geranospiza caerulescens], Zone-tailed Hawk [B. albonotatus], and Oriental Honey-buzzard [Pernis ptilorhyncus]) evidence many features of the Golden Eagle tail (Table 1). For example, there are dark shafts in the light bars, more heavily pigmented outer webs, and deeper pigmentation on rectrix 6 . An interesting deviation is that, unlike the juvenile Golden Eagle, the light zones on the centrals of the Crane Hawk (Fig. 15b) are not darker than light zones in other rectrices.

In two pale-tailed raptors (Fig. 15e, f), the Ferruginous Hawk (B. regalis) and the Upland Buzzard ( $B$. hemilasius), dark pigment is located, as in the eagle, mostly where it is exposed to the sun when the tail is folded.

Three white-tailed species (Fig. 16a) show extensive degradation, especially of the outer vane. Tail damage in the White-tailed Eagle (Haliaeetus albicilla) and Ferruginous Hawk is so extensive by time of molt that this epigamic feature (i.e., pale tail) probably persists only because adults would be excluded from breeding without it.

Two species of falcons, the Gyrfalcon (Falco rusticolus) and the Saker Falcon (F. cherrug; Fig. 16ac), show Golden Eagle traits such as darker centrals, pale tips, and dark conspicuous on shafts in white/ pale zones. The Gyrfalcon (Fig. 16b) also shows outer webs darker (except for centrals), but the saker does not. Note also that the extreme margins of the outer webs of tail and wing for both species are pale; this is opposite the condition in the Golden Eagle. Perhaps greater flexibility is here adaptive.

Another species available to me to test the pigmentation rules is the White Hawk (Leucopternis albicollis; Fig. 16d), a species of the rain forest. Only the black subterminal band and a broad white tip follow the Golden Eagle trends. Strangely, the black band, rather than being wider near the rachi, is there narrower. Even the outer web of the outer primary is white basally rather than dark.

For the Great Black Hawk (Buteogallus urubitinga), the juvenile (Fig. 16e) shows many parallels (Table 1) with the juvenile Golden Eagle. The black line along the inner margin of most rectrices seems to amplify a Golden Eagle trait, but with uncertain significance.

In the Red-backed Hawk (Buteo polyosoma; Fig. 16f), many features parallel those of the Golden Eagle, especially the dark distal portions of the shafts. Note that the regular barred pattern evident in L1-6 was somehow disrupted in R6 from the opposite side of the tail. This illustrates the point that the locations of some blotches and spots are, at this level of investigation, inexplicable.

In Fig. 17a, b, two species from disparate genera (i.e., the Northern Harrier [Circus cyaneus] and the Cooper's Hawk [Accipiter cooperii]) show similar traits. Some features parallel those in the Golden Eagle (Table 1), but note that the outermost rectrix, at least for the harrier, is actually the palest. Both are long-tailed species; both tails are much more flexible than those of other raptors we have discussed except the Crane Hawk. I suggest that the need for flexibility dictates that outer rectrices be pale.

In Fig. 17c, a juvenile Yellow-headed Caracara (Milvago chimachima) exhibits a trait common to large falcons (see Fig. 17e), but of unknown significance. Namely, the broadest dark tail bar is not the most distal. However, many Golden Eagle traits are still evident (Table 1).

The only owl, a Spotted Eagle Owl (Bubo africanus; Fig. 17d), shows traits common to others in the genus Bubo and to a degree in Strix and Tyto. Several Golden Eagle traits are still evident (Table 1), but, just as in the harrier (Fig. 17a), the outer rectrix is the palest in the owl, presumably for increased flexibility.

In Fig. 17e, four species are represented. The left most rectrix, an R5 from an adult Harlan's Hawk (Buteo jamaicensis harlani), exhibits many Golden Eagle features, as does the right most, an L6 from a subadult Bald Eagle (H. leucocephalus). Remarkably, the Bald Eagle, before abandoning the last vestiges of protective dark as it achieves adulthood, produced a feather so like that of a juvenile Golden Eagle.

The preceding paragraphs illustrate the prevalence of many Golden Eagle pigmentation traits: the final tail (Cactus Wren [Campylorhynchus brunneicapillus]; Fig. 17f) is included because it seemingly violates nearly every Golden Eagle rule. The terminus is black not white, the subterminal band is white not black, the base is black not white. The outer and central rectrices are the palest not the darkest, and the outer web of the outer rectrix is paler than any other web not darker than any other 

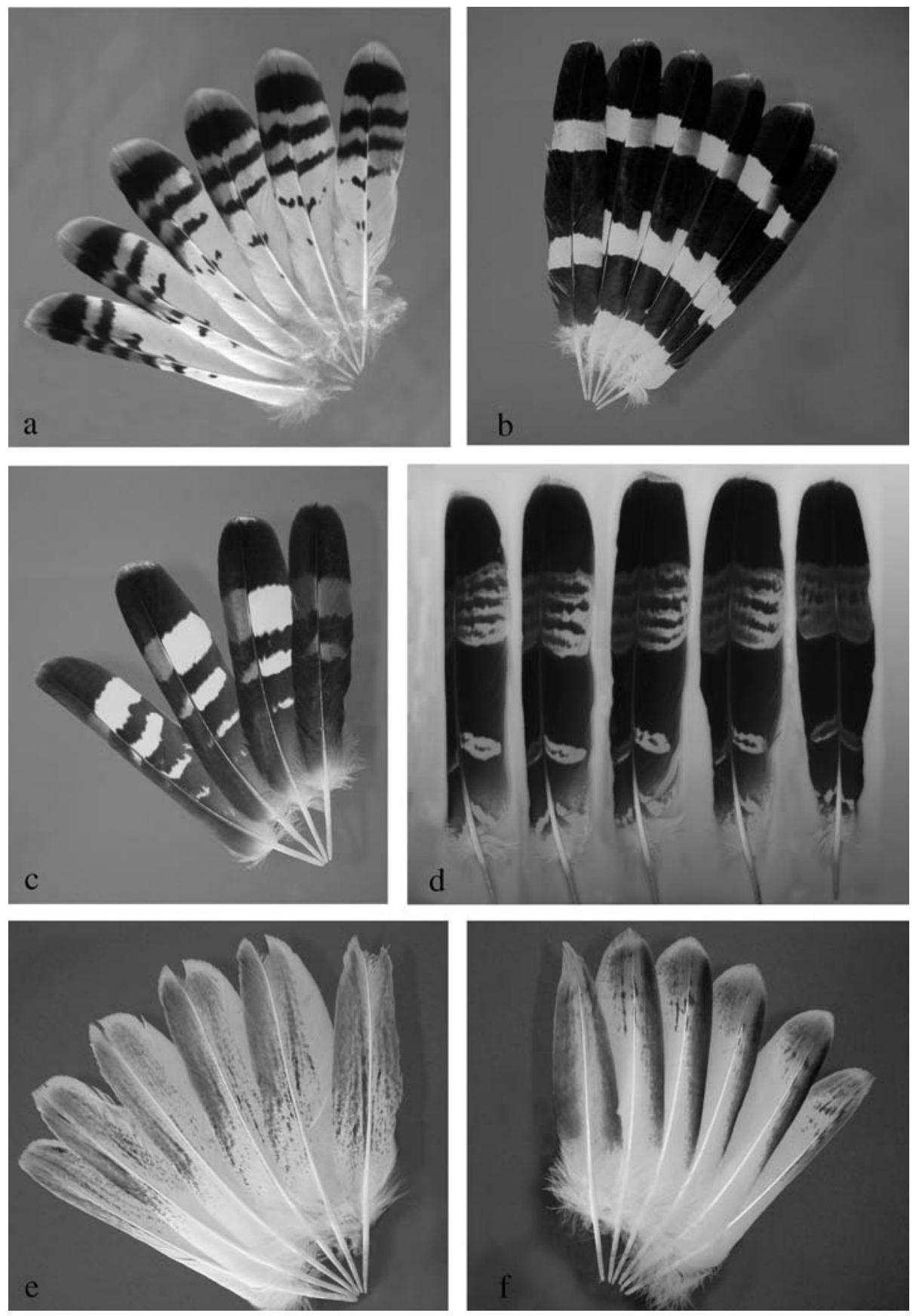

Figure 15. Rectrices from six raptors showing pigmentation features for comparison with the juvenile Golden Eagle (Table 1): (a) adult male Rough-legged Hawk (November 1999, roadkill, Utah U.S.A.), (b) adult Crane Hawk (February 1996, Sonora, Mexico), (c) adult female Zone-tailed Hawk (June 1979, shot by nest, Arizona), (d) adult Oriental Honeybuzzard (June 1997, raptor kill, eastern Mongolia), (e) adult, rufous morph Ferruginous Hawk (May 1974, shot on nest, north-central Montana), and (f) adult, pale morph Upland Buzzard (May 1995, electrocution, central Mongolia). 

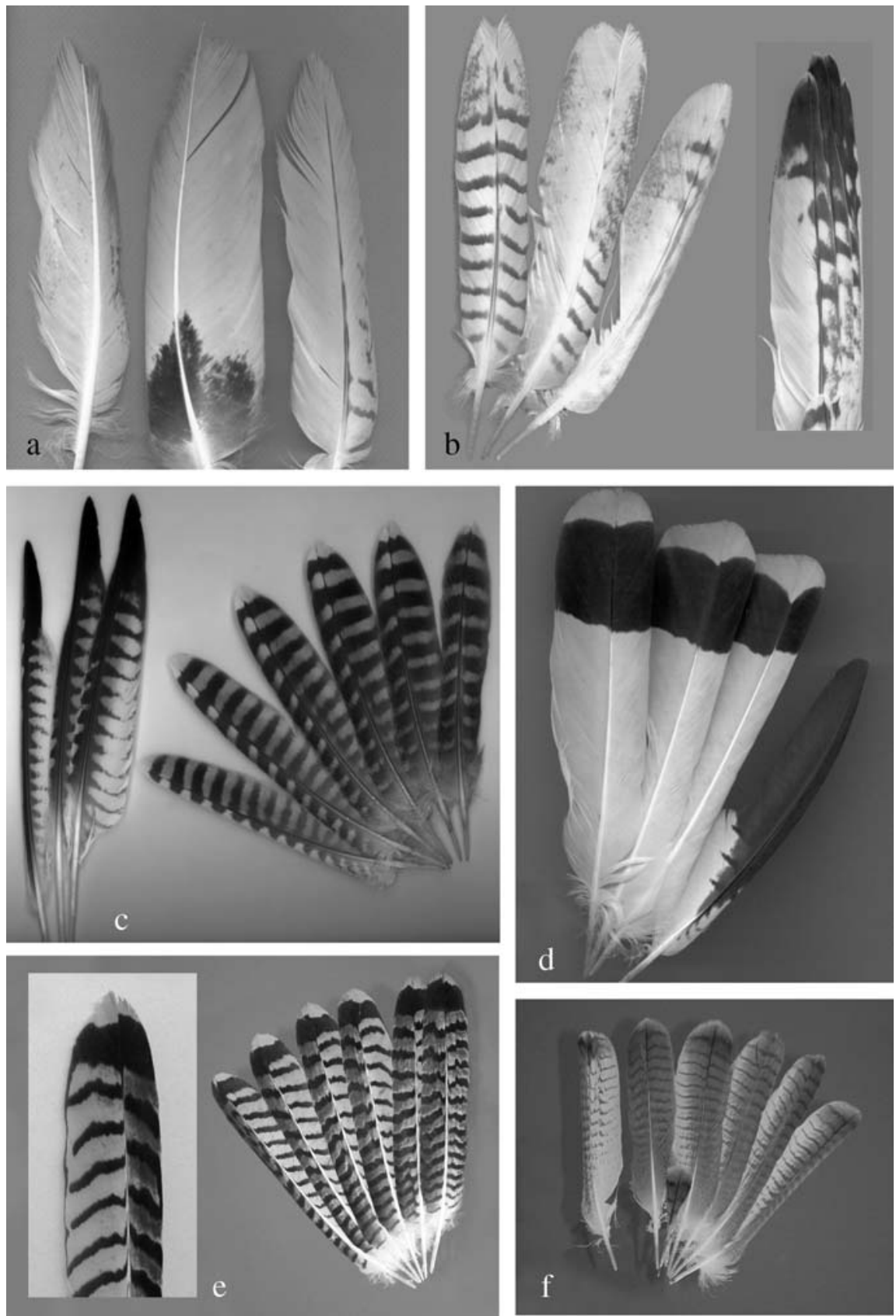

Figure 16. Rectrices from seven raptors. These show pigmentation features compared in Table 1. (a) Heavily damaged pale feathers: left, molted rectrix (L5) from Ferruginous Hawk (2002, Montana); middle, molted rectrix (R5) from White-tailed Eagle (1990, northwestern Siberia); right, worn, but not molted, rectrix (L3, L4, or L5) from Gyrfalcon (1986, trap mortality, northeastern Siberia). (b) Three rectrices and wing tip from same Gyrfalcon as in a; wing shows white leading edge. (c) Adult male Saker Falcon (found July 1995, desiccated, eastern Mongolia). Note pale leading edge of wing. (d) White Hawk rectrices and outermost primary (January 1978, shot, eastern Panama). (e) Juvenile Great Black Hawk (recovered February 1978, shot, Guatemala). Note (inset) black line on the edge of the inner web (L4). (f) Redbacked Hawk, extra rectrix (R6) shows unusual disruption of bar pattern (March 1979, southern Argentina). 

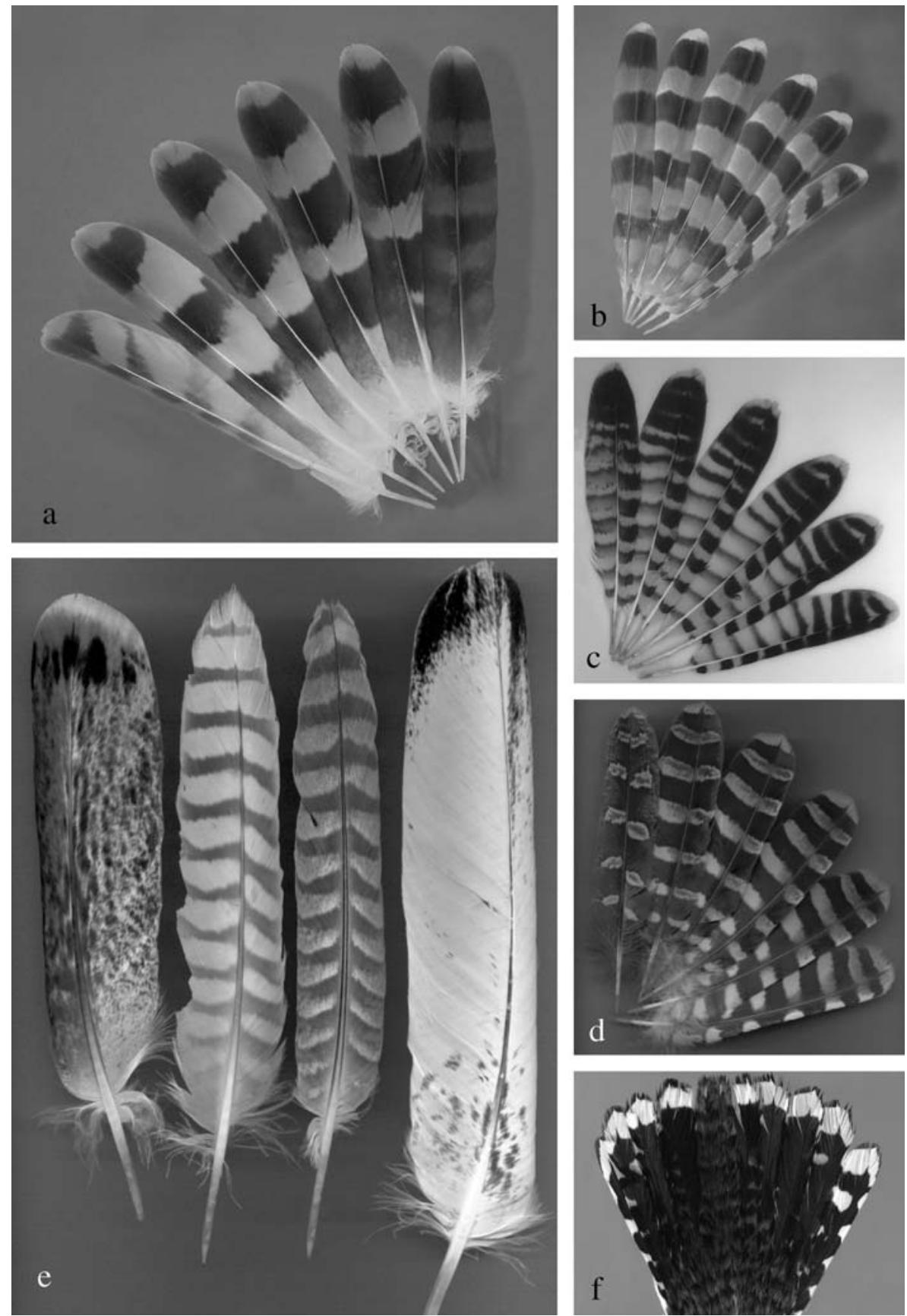

Figure 17. Rectrices from nine species. (a) Juvenile male Northern Harrier (October 1973, Montana). Lateral rectrix is palest of all. True also for d and f. (b) Juvenile male Cooper's Hawk (August 1975, Arizona). (c) Fledgling Yellow-headed Caracara (April 1979, roadkill, Venezuela). The broadest dark bar for this and some other species on this page is not the distal most. (d) Spotted Eagle Owl (February 1994, roadkill, South Africa). (e) Left, adult Harlan's Hawk, R5 (2002, roadkill, Oklahoma); left middle, adult female Saker Falcon, L2 (June 1995, molted, eastern Mongolia); right middle, adult male Gyrfalcon, rectrix L1 (August 1992, molted, northeastern Siberia); right, subadult Bald Eagle, L6 (molted, no other data). (f) Cactus Wren (September 1982, trap mortality, Arizona) showing reversal of several Golden Eagle traits. 


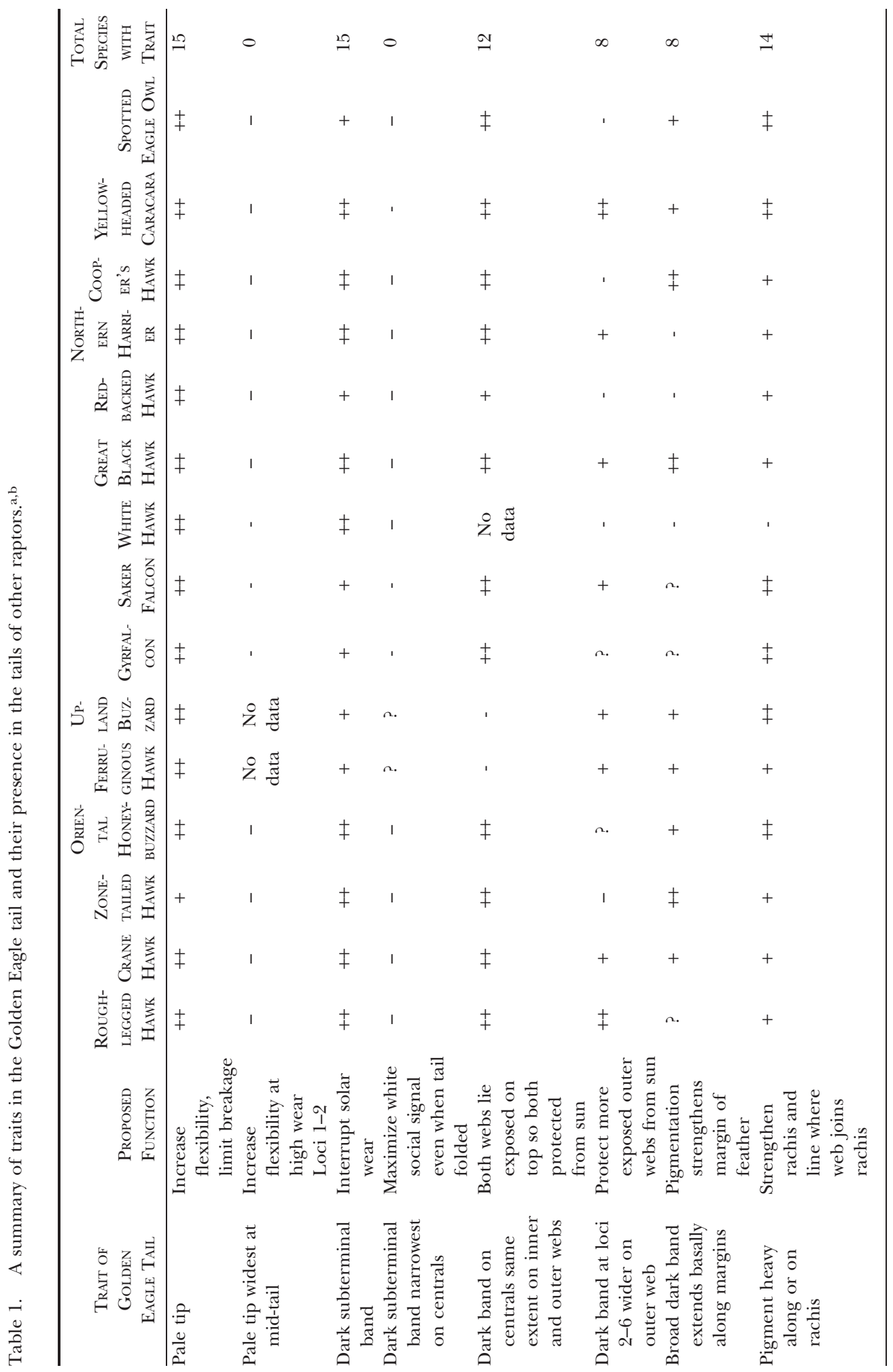


ELLIS AND LisH

Vol. 40 , No. 1

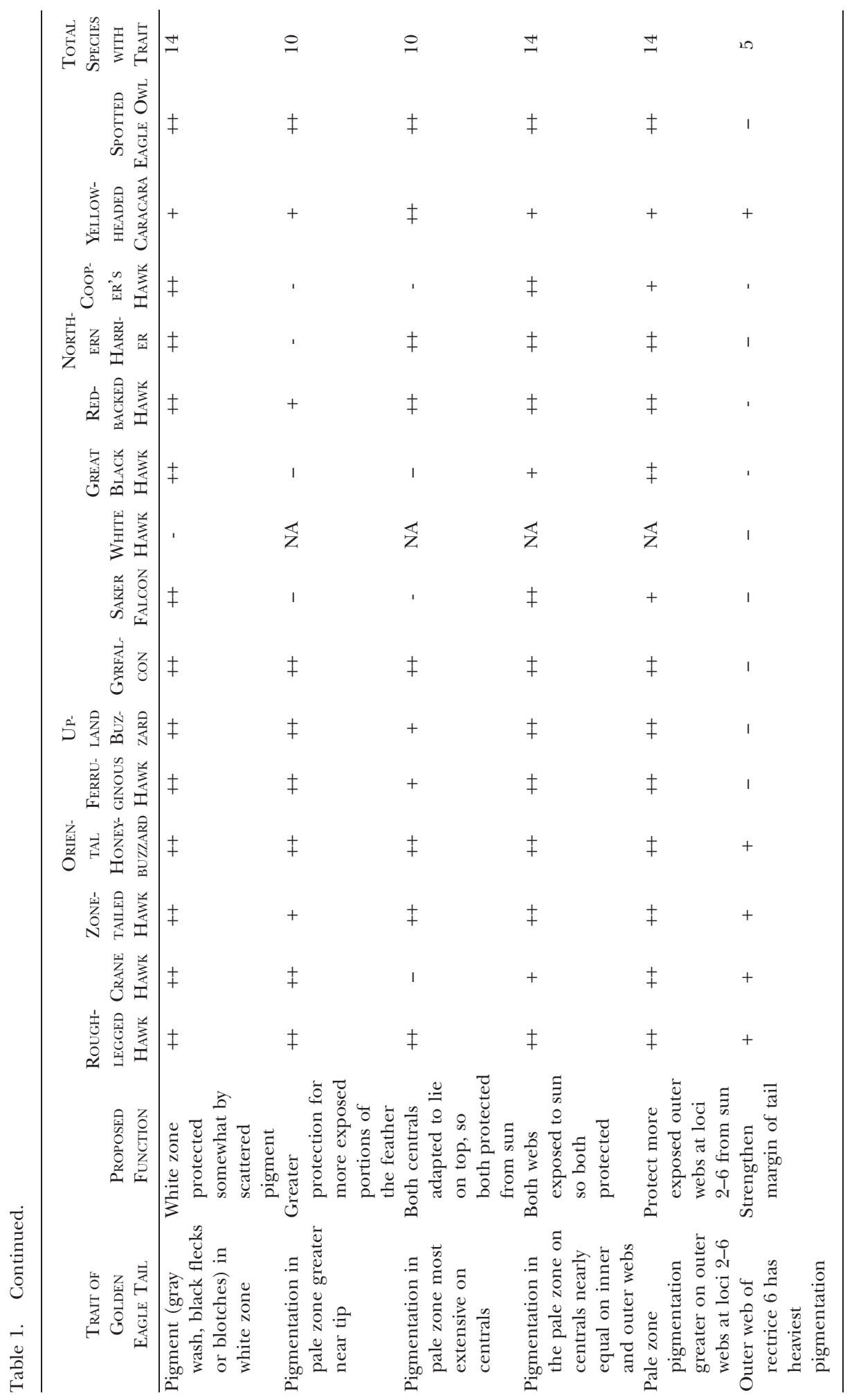


web as in the Golden Eagle. As stated by $\mathrm{P}$. Stettenheim (pers. comm.), "... few rules of feather pigmentation hold true for all birds." The importance of each trait for each species must come from observation, then experimentation with that species.

Are Common Traits Adaptive? In comparing 15 species representing two avian orders (Table 1), several displayed Golden Eagle tail characteristics. The most common traits include a pale terminal band (all species), dark subterminal band (all species), dark along the rachis (14 species), pigmentation of inner webs of centrals dark like outer webs of other rectrices (14 species), and outer webs more heavily pigmented than inner webs (14 species). Surprisingly, the outer web of the lateral rectrices (Table 1, row 14) was the darkest vane in only five species. Perhaps for aerodynamic purposes, the dark web is more important in the much larger eagle.

When totaled, most of the traits were found in most species (Table 1). The greatest divergence was for the White Hawk, an inhabitant of forest shadows. The fact that such a wide variety of species shows so many of the Golden Eagle traits suggests the adaptive value of common traits.

Complexities in Golden Eagle Plumage. Many of the eagle feathers illustrating this article were chosen because they provide clear examples of each particular trait. However, the reader can generally assess the prevalence of a trait by searching through my figures to see how many feathers (i.e., among those not chosen specifically to illustrate that principle) do exemplify that trait. It is evident by now that subtle patterns of light and dark in many Golden Eagle feathers defy explanation. In Fig. 2, for example, why are some rectrices at the same loci barred, while others are streaked or spotted? I suspect that such variation is valuable in the recognition of individual birds and for other social purposes.

\section{Discussion And Conclusions}

Reexamining Theorized Functions of Dark Plumage. My purpose was to identify the functional morphology of many traits in the Golden Eagle tail. Burtt's $(1979,1986)$ evidence, from blasting feathers with powdered glass, showed that dark plumage resists abrasion better than pale. His ultraviolet (UV) light experiments also provide convincing evidence that dark feathers do much better in inhibiting UV transmission to the body. My observations of bleaching and fraying suggest that dark pigment may be most important in protecting the 
plumage itself, first from solar wear and second from abrasion due to contact with a substrate.

Burtt $(1979,1986)$ found that dorsal surfaces of an airfoil receive higher velocity collisions with dust particles (hence the need for greater pigmentation on the dorsum). Inasmuch as angle of incidence is a primary factor in determining the destructive force of a collision, it should be clear that the surfaces that present themselves at right (or high) angles to the airstream absorb most of the energy of a collision. If abrasion is the primary factor in selecting for the placement of melanin, then high impact surfaces (e.g., those on the leading edge of the wing and the forehead) should be the most deeply pigmented, yet in many raptors they are not.

Abrasion surely must be an important factor for some species, but a scan of a broad spectrum of bird families shows that abrasion of plumage is most pronounced where it is most likely due to contact with a substrate (especially soil, but also vegetation). However, for many species, most plumage wear appears as bleaching, most likely from the sun. For the Golden Eagle, museum specimens show heavy wear on rectrix tips (probably due to abrasion with a substrate), lesser wear on primary tips, very little wear on secondary tips, and extensive bleaching and fraying of feathers most subject to insolation. Most of the feather damage that I have observed in captive eagles and damage in feather wear experiments comes from bleaching and could not be due to collision with dust during flight.

Burtt's (1979) conclusion that dark plumage also protects the body from UV light seems well justified and most birds show countershading. However, a wide variety of species have extensive pale, even white, patches on the dorsum. If Burtt's (1999) body protection hypothesis was correct, we would expect to see, among birds from sun-drenched environments (especially deserts where more soil particles are aloft), a preponderance of species with very dark plumage from forehead to tail coverts and over the fleshy portions of the wing. However, Zink and Remsen (1986) found that birds from high deserts tend to be pale and birds of forest shadows and rainy, sunless environments tend to be dark (this is in keeping with Gloger's Rule).

To me, the most convincing evidence for the primary source of natural wear comes from examining feathers in wild and captive birds. In the Golden Eagle, the locations of high wear zones provided clear evidence that most wear to the tail and the wing occurred when neither the wing nor the tail was spread (Figs. 1a, 1d, and 12). The agent responsible for the silhouette-like bleaching in Fig. 1d did its damage when the birds were not flying. The most likely agent of this wear is the sun (probably in combination with other weather factors). Burtt (1981) included "reduced bleaching" as one of many hypothetical functions for dark pigment in feathers. He (Burtt 1986:18) also noted that wear was most extensive at the center of woodwarbler tails, and Burtt and Gatz (1982) stated that the central and lateral rectrices were areas of high turbulence (an assertion seemingly at odds with models of aerodynamics [Thomas 1993]), and therefore were subject to high levels of abrasive wear.

Why the Golden Eagle? The logic in this paper relies heavily on wear patterns in white zones in young Golden Eagles. The Golden Eagle is an excellent choice for examining pigmentation rules because of long retention times for the feathers (1-3 yr) and the conflict between selective pressure to display conspicuous sign stimuli (white patches) while protecting white zones with dark pigment. Finally, the Golden Eagle's niche as a predator of relatively large mammals results in considerable feather trauma, hence the need for plumage that minimizes abrasive wear. The interplay between these three selective pressures results in the display of a score of pigmentation traits which benefit the eagle by increasing feather longevity and benefit us by revealing the means whereby a bird survives with pale plumage patches under such conditions.

Applying the principles in Fig. 14 to Golden Eagle populations worldwide and assuming that the white zones have an important communication function to minimize adult aggression, logic suggests that dark pigment in pale areas on the juvenile wing and tail will be most prevalent and most conspicuous in populations where incident light is greatest (e.g., in high elevation deserts). Here a darker tail should be favored unless breeding, perching, and roosting structures are very limited and where, as a result, the juvenile is at great risk of attack as it attempts to use these limited resources. In overcast climes, a dark tail is less needed, so most juveniles could survive with very white tails. In regions where the eagles are sedentary and where juvenile dispersal is limited, a large white zone is less needed, so a dark tail could be favored. I submit that young birds in Golden Eagle populations around the world face these conflicting selective pressures with the result that the birds that survive have, on average, the best mix of adaptive genes for their peculiar situation. 


\section{ACKNOWLEDGMENTS}

For access to specimens, thanks go to the U.S. National Museum (Smithsonian Institution, USNM), British Museum, American Museum of Natural History, and the University of Arizona ornithological collection. For assistance in preparing the plates, I thank Carl Hanson, Jim DiLoreto, and Carla Dove (all three at USNM), Chris Gunn (National Aeronautics and Space Administration [NASA]-Goddard Space Flight Center [Goddard]), Kinard Boone (U.S. Geological Survey, Patuxent Wildlife Research Center), and most importantly, Merlin H. Ellis. For detailed comments on the manuscript and help with the literature, I am deeply indebted to Edward H. Burtt, Jr. For helpful comments, I also thank Ian Newton, Dean Hector, C.T. LaRue, R. Zusi, Peter Stettenheim, and Carla Dove. I am most grateful to Jim Bednarz, Journal of Raptor Research Editor, for allowing this oversized and highly-theoretical paper. Publication costs were paid by NASA-Goddard and Department of Physiological Sciences, Center for Veterinary Health Sciences, Oklahoma State University.

\section{Literature Cited}

Amadon, D. 1980. Varying proportions between young and old raptors. Proc. IV Pan-Afr. Orn. Congr. 327-331.

Averill, C.K. 1923. Black wing tips. Condor 25:57-59.

Barrowclough, G.F. and F.C. Sibley. 1980. Feather pigmentation and abrasion: test of a hypothesis. Auk 97:881-883.

Beletsky, L. 1996. The Red-winged Blackbird: the biology of a strongly polygynous songbird. Academic Press, London, United Kingdom.

BeNT, A.C. 1921. Life histories of North American gulls and terns. Bull. 113, U.S. National Museum, Washington, DC U.S.A.

Bergman, G. 1982. Why are the wings of Larus f. fuscus so dark? Ornis Fenn. 59:77-83.

BloOm, P.H. and W.S. Clark. 2001. Molt and sequence of plumages of Golden Eagles and a technique for inhand ageing. N. Am. Bird Bander 26:97-116.

Bonser, R.H.C. 1995. Melanin and the abrasion resistance of feathers. Condor 97:590-591.

BurtT, E.H., JR. 1979. Tips on wings and other things. Pages 75-110 in E.H. Burtt, Jr. [ED.], The behavioral significance of color. Garland STPM Press, New York, NY U.S.A.

1981. The adaptiveness of animal colors. BioScience 31:723-729.

-1986. An analysis of physical, physiological, and optical aspects of avian coloration with emphasis on wood-warblers. Ornith. Mono. 38:1-126.

- 1999. Rules to bird by: Gloger's Rule and Allen's Rule. Birding 31:362-365.

— AND A.J. GATZ, JR. 1982. Color convergence: is it only mimetic? Am. Nat. 119:738-740.

— AND J.M. ICHIDA. 1999. Occurrence of featherdegrading bacilli in the plumage of birds. Auk 116:364-372.
Chandler, A.C. 1916. A study of the structure of feathers with reference to their taxonomic significance. Univ. Calif. Publ. Zool. 13:243-446.

Clark, W.S. and B. Wheeler. 1983. The field identification of North American eagles. Am. Birds 37:822-826.

Coтt, H.B. 1966. Adaptive coloration in animals. Methuen, London, United Kingdom.

Crane, K. and K. Nellist. 1999. Island eagles: 20 years observing Golden Eagles on the Isle of Skye. Cartwheeling Press, Isle of Skye, United Kingdom.

Cuthill, I.C., J.C. Partridge, A.T.D. Bennett, S.C. Church, N.S. Hart, AND S. Hunt. 2000. Ultraviolet vision in birds. Adv. Study Behav. 29:159-214.

Dekker, D. 1999. Bolt from the blue: wild peregrines on the hunt. Hancock House Publishers, Surrey, British Columbia, Canada.

ELLIS, D.H. 1979. Development of behavior in the Golden Eagle. Wildl. Monogr. 70:1-94.

- 2004. Mottling in the plumage of juvenile Golden Eagles. N. Am. Bird Bander 29:53-58.

- AND M. Kéry. 2004. Variable retention times for rectrices at different loci in a Golden Eagle. J. Raptor Res. 38:270-275.

Goldstein, G., K.R. Flory, B.A. Browne, S. Majid, J.M. ICHIDA, AND E.H. BuRTt, JR. 2004. Bacterial degradation of black and white feathers. Auk 121:656-659.

GrubB, T.C., JR. 1989. Ptilochronology: feather growth bars as indicators of nutritional status. Auk 106:314-320.

Hailman, J.P. 1976. Uses of the comparative study of behavior. Pages 13-22 in R.B. Masterton, W. Hodos, and H. Jerison [EDs.], Evolution, brain, and behavior: persistent problems. Lawrence Erlbaum Associates Publishers, Hillsdale, NJ U.S.A.

Hedenström, A. And S. SunAda. 1999. On the aerodynamics of moult gaps in birds. J. Exp. Biol. 202:67-76.

Jollie, M. 1947. Plumage changes in the Golden Eagle. Auk 64:549-576.

King, J.R. And M.E. Murphy. 1984. Fault bars in the feathers of White-crowned Sparrows: dietary deficiency or stress of captivity and handling? Auk 101:168-169.

Lucas, A.M. And P.R. Stettenheim. 1972. Avian anatomy: integument. Parts I and II. Agriculture Handbook 362. U.S. Department of Agriculture, Washington, DC U.S.A.

Montalenti, G. 1934. A physiological analysis of the barred pattern in Plymouth Rock [chicken] feathers. J. Exp. Zool. 69:269-345.

Moyer, B.R. and D.H. Clayton. 2004. Avian defenses against ectoparasites. Pages 241-257 in H.F. van Emden and M. Rothschild [EDs.], Insect and bird interactions. Intercept, Andover, Hampshire, United Kingdom.

Palmer, R.S. [ED.] 1988. Handbook of North American birds. Vol. 5. Yale University Press, New Haven, CT U.S.A.

Roulin, A., C. Riols, C. Dykstra, and A.-L. Ducrest. 2001. Female plumage spottiness signals parasite resistance in the Barn Owl (Tyto alba). Behav. Ecol. 12:103-110. 
SAGE, B.L. 1962. Albinism and melanism in birds. Br. Birds 55:201-225.

Shawkey, M.D. and G.E. Hill. 2004. Feathers at a fine scale. Auk 121:652-655.

Sundevall, C.J. 1886. On the wings of birds. Ibis 4:389-457.

Swaddle, J.P., M.S. Witter, I.C. Cuthill, A. Budden, And P. McCowen. 1996. Plumage condition affects flight performance in Common Starlings: implications for developmental homeostasis, abrasion and moult. $J$. Avian Biol. 27:103-111.

Test, F.H. 1940. Effects of natural abrasion and oxidation on the coloration of flickers. Condor 42:76-80.

Thomas, A.L.R. 1993. The aerodynamic costs of asymmetry in the wings and tail of birds: asymmetric birds can't fly round tight corners. Proc. R. Soc. Lond. B. Biol. Sci. 254:181-189.

Tinbergen, N. 1963. Behavior and natural selection. Pages 519-542 in Proc. XVI Int. Cong. Zool. Washington, DC U.S.A.

TJERNBERG, M. 1977. Individuell igenkänning av kungsörnar Aquila chrysaetos i fält samt resultat av vinterinventeringar i sydvästra Uppland. [Individual recognition of
Golden Eagles Aquila chrysaetos in the field, and results of winter censuses in southwest Uppland, central Sweden.] Vår Fågelvärld 36:21-32.

Tucker, V.A. 1991. The effect of molting on the gliding performance of a Harris' Hawk (Parabuteo unicinctus). Auk 108:108-113.

Vortkevich, A.A. 1966. The feathers and plumage of birds. Sidgwick and Jackson, London, United Kingdom.

WALSBERG, G.E. 1983. Coat color and solar heat gain in animals. BioScience 33:88-91.

Watson, G.E. 1963. The mechanism of feather replacement during natural molt. Auk 80:486-495.

Watson, J. 1997. The Golden Eagle. T. and A.D. Poyser Ltd., London, United Kingdom.

Zahavi, A. And A. Zahavi. 1997. The handicap principle: a missing piece of Darwin's puzzle. Oxford University Press, Oxford, United Kingdom.

Zink, R.M. AND J.V. Remsen, JR. 1986. Evolutionary processes and patterns of geographic variation in birds. Curr. Ornithol. 4:1-69.

Received 14 May 2004; accepted 13 November 2005 